Article

\title{
Entrepreneurship Education through Successful Entrepreneurial Models in Higher Education Institutions
}

\author{
Gabriela Boldureanu ${ }^{1, *}$, Alina Măriuca Ionescu ${ }^{1}$, Ana-Maria Bercu ${ }^{2}$ (D), \\ Maria Viorica Bedrule-Grigoruță ${ }^{1}$ and Daniel Boldureanu ${ }^{3}$ \\ 1 Department of Management, Marketing and Business Administration, Alexandru Ioan Cuza University of \\ Iasi, 700506 Iasi, Romania; alina.ionescu@yahoo.com (A.M.I.); maria.bedrulegrigoruta@uaic.ro (M.V.B.-G.) \\ 2 Department of Finance, Money and Public Administration, Alexandru Ioan Cuza University of Iasi, \\ 700506 Iasi, Romania; bercu@uaic.ro \\ 3 Department of Biomedical Sciences, Faculty of Medical Bioengineering, Grigore T. Popa University of \\ Medicine and Pharmacy of Iasi, 700115 Iasi, Romania; daniel.boldureanu@umfiasi.ro \\ * Correspondence: gboldureanu@gmail.com; Tel.: +40-745934720
}

Received: 25 October 2019; Accepted: 5 February 2020; Published: 10 February 2020

\begin{abstract}
In higher education institutions, entrepreneurship learning based on successful entrepreneurial role models may promote education for sustainable development. Several theoretical perspectives, such as the human capital theory, the entrepreneurial self-efficacy and self-determination theory, argue that entrepreneurship education is positively correlated with entrepreneurial intentions of students, as it provides adequate know-how and skills and motivates them to develop their entrepreneurial careers. In entrepreneurship education programmes, exposure to successful entrepreneurial models could be a significant factor for stimulating students' confidence in their ability to start a business and for improving their attitudes towards entrepreneurship. This study aims (i) to identify characteristics viewed by students as being specific to a successful entrepreneur, (ii) to establish the influence of exposure to successful entrepreneurial role models (chosen by students) during entrepreneurship education classes on student entrepreneurial intentions, and (iii) to assess how such exposure influences the attitudes of students towards entrepreneurship. For this purpose, the authors ran a pilot experiment with 30 graduate students enrolled in a Business Creation course using a research methodology that combined qualitative techniques with quantitative measures. Content and statistical analyses were utilised to examine differences in student entrepreneurial intentions and attitudes towards entrepreneurship after being exposed to successful entrepreneurial models. Our study provides evidence that entrepreneurship education based on successful entrepreneurial role models may positively influence the entrepreneurial attitudes and intentions of students and could lead to higher orientation of student perception towards social benefits of entrepreneurship (new jobs) compared to financial ones (high income). However, our findings stress that if educators want to improve the efficiency of education focused on developing entrepreneurial skills, graduate programmes should be designed differently for business and non-business students, since studying successful entrepreneurial stories impacts these two groups differently.
\end{abstract}

Keywords: entrepreneurship education; entrepreneurial role model; entrepreneurial intention; successful entrepreneurs

\section{Introduction}

Entrepreneurship is a key element for any country aiming to be competitive in the knowledge-based global market due to the fact that it has been generally viewed as a method promoting economic 
growth, creativity, and innovation. This view has led to a growing interest in developing educational programmes that encourage and enhance entrepreneurship.

Although a consensus has not been reached on whether entrepreneurship can be encouraged through education, a significant amount of literature on this issue [1-5] acknowledges the positive contribution of entrepreneurship education on the development of people's know-how, skills, as well as on the enhancement of entrepreneurial attitude and intention.

As for the integration of entrepreneurship education into higher education, studies $[6,7]$ stress its importance, so that 21st century universities can become important engines of technological development and economic growth.

Inclusion into academic programmes of specific disciplines dealing with company creation [8], creation of self-employment support units and university seedbed development, or creativity and entrepreneurship workshops are a few examples of initiatives developed within universities aimed to encourage students to create companies [5]. Moreover, educational institutions make yearly efforts to provide students with entrepreneurial role models in the classrooms [9].

In Romania, starting in 2002, the Ministry of Education and Research, mostly due to the pressure of international programmes, introduced the discipline Entrepreneurial Education into secondary education curricula, and later, in 2013, into higher education programmes when the EU adopted the 2020 Entrepreneurship Action Plan [10], which, along with other provisions, streamlined the development of entrepreneurship education and training.

In the last years, Romanian universities have taken significant steps to integrate entrepreneurship education into academic programmes at all higher education insitutions. These measures mainly include introduction of theoretical courses on entrepreneurship into the curricula for undergraduate and graduate students, and organization of events promoting entrepreneurship. These events are aimed to create and develop a pro-entrepreneurial attitude among students and to equip them with knowledge on entrepreneurship to make them view entrepreneurship as a viable career option [11]. Communication with the business community and student involvement in this process have been facilitated through business hub infrastructure. Student entrepreneurial associations and technology transfer centres have been set up in several Romanian universities, but there are still only a few such centres.

Even if there had been several initiatives employing different pedagogical designs for entrepreneurship education, things have started to change quite recently, and few attempts have been undertaken to assess how different teaching methods of entrepreneurship education influence the attitude towards entrepreneurship and the entrepreneurial intentions of students in Romanian universities. Even less studied is the degree to which pedagogical design of entrepreneurship education within master's programmes has similar or different effects on different BA degree graduates. In fact, researchers identified the need of deeper investigation that directly links student/graduate entrepreneurial outcomes to different pedagogical methods [12], as well as the need to consider how the contextual factors, such as student background in entrepreneurship education, impact research [13].

This study fills this knowledge gap and describes a pilot experience that was carried out with graduate students enrolled in a Business Creation course in a Romanian university, with the aim to assess the influence of exposure to successful entrepreneurial models on students by taking into consideration the views of students on entrepreneurial success. This way, each participant chooses his or her own model, learning from it, but also learns from the role models chosen by their peers.

Individuals are attracted to role models they perceive as being similar to them in terms of their characteristics, behaviour or goals (role aspect), and from whom they can learn specific skills or competencies (model aspect) [9]. Therefore, a successful entrepreneur possessing such characteristics could enable an individual to cope with the challenges and demands of the business environment. Studies report that successful entrepreneurial models can have a positive impact on both the attitudes of individuals towards entrepreneurship and on their entrepreneurial intentions [9,14-24]. 
Although the existence of entrepreneurial models has become a common practice, the influence of these role models on entrepreneurial attitudes and intentions of students has not been researched enough in the academic context.

The goals of our research are threefold: (i) to identify which characteristics students view as being specific to a successful entrepreneur; (ii) to establish the influence that the exposure to successful entrepreneurial role models (chosen by students) during entrepreneurship education classes has on student entrepreneurial intentions; (iii) to establish how this exposure influences the attitudes of students towards entrepreneurship.

For this purpose, we have designed several research steps. The study first presents the theoretical framework that includes a literature review of successful entrepreneur profiling and the influence of entrepreneurial role models on entrepreneurial intention and attitude towards entrepreneurship. Then, the review is used to formulate the research questions and to streamline the role of student exposure to successful entrepreneurial models in entrepreneurship education. The next section describes the research methodology (sample and data collection, research steps, used methods). Finally, we discuss the main results concerning student perceptions of successful entrepreneur profiles, and present our findings on how student perceptions of entrepreneurship have changed due to their exposure to successful entrepreneurial models.

\section{Theoretical Framework and Hypotheses}

\subsection{Successful Entrepreneur Profile}

Both researchers and experts in entrepreneurship have reported that establishment of new companies is a key element in the process of development and growth [25], the entrepreneur being defined as an individual undertaking risks, making plans, supervising and monitoring, organizing and controlling the business [26], as well as maximizing business opportunities [27], taking the initiatives, organizing the socio-economic mechanisms and accepting the risk of failure [28], being a leader and an innovator [29].

William Gartner [30] conducted an extensive study comparing the main research on entrepreneurship. Gartner's study reported on a number of characteristics of entrepreneurs, such as preference for risk, independence, optimism, creativity, initiative, leadership, desire for success, etc.

In more recent studies, there are found features outlining the profile of a classical entrepreneur, namely, a developed sense of independence, the desire to take responsibility and run a business, increased capacity for intense and lasting effort, preference for moderate risk-taking in business; rapid reaction, prompt decisions in current activity, efficient organization of working time [31].

What distinguishes a classical entrepreneur from a modern one are the characteristics enabling an entrepreneur cope with the ongoing challenges and demands of the business environment. A study conducted in northeastern Thailand on a sample of 391 entrepreneurs identified a series of characteristics of successful entrepreneurs: a spirit of business, proactivity, competitive advantage, sustainability, orientation towards human capital and company performance [32]. Also, the characteristics of successful entrepreneurs differ by stage of business development [33]. However, regardless of their business development stage, the orientation towards the future and the less fatalistic perspective are linked to greater success in entrepreneurship.

A more unconventional approach to successful entrepreneur profiling was suggested by Jeremy Snepar [34], who contends that entrepreneurs feel comfortable with professional discomfort. So, entrepreneurs risk their reputations and livelihoods to follow an unconventional or unpopular approach to solving a problem [34] (p. 1521).

It seems that today resilience is one of the most important features of successful entrepreneurs. Resilience enables entrepreneurs to overcome crises, critical situations, and to get over failures, emerging even stronger than before. Entrepreneurial resilience is a less debated topic, the main two lines of research being focused on behaviour and experience of parents and the two process-linked 
factors (entrepreneurial learning and experience, as well as the entrepreneur's professional attitude and behaviour) [35].

\subsection{Entrepreneurial Role Models}

It has generally been accepted that the existence of an entrepreneurial role model is a key influence factor in the entrepreneur's decision to start a business. A significant part of the literature in the field on the decision to start a business includes background or antecedent factors that underlie the entrepreneurial decision, including the role model's influence on the thinking process of the potential entrepreneur [36].

The effect of role models is a sociological phenomenon that has been extensively studied [37,38]. In entrepreneurship research $[21,39]$, it is used as an informal institutional factor that can act as an incentive for entrepreneurial activity [23]. Fornahl [20] noted the positive role that entrepreneurial examples play among the institutional factors influencing entrepreneurial activity.

Individual decisions to adopt certain behaviour are often influenced by the behaviour and opinions of other individuals through the example provided and the identity they display [40]. This is also the case with occupational choice [41], in general, and the choice of becoming an entrepreneur [18], in particular, as many entrepreneurs declare that the decision to go into business and the way they have developed their businesses have been influenced by the examples of other people who have served as entrepreneurial models [21]. Role models refer to individuals who provide examples that can be followed by others, and which may stimulate or inspire other individuals to make certain decisions, including career-related decisions, and to reach certain goals [21]. Gibson [38,42] defined the role model as a person whom an individual perceives as being, to a certain extent, similar to himor herself, and, because of this similarity, the individual wishes to imitate (or to avoid, in particular) certain characteristics or behaviours of that person [43].

In his dissertation, McCullough [43] adopts a slightly modified version of Gibson's definition, describing the role model as a person with whom an individual identifies him- or herself to some degree, and whom one may wish to emulate (or avoid). This definition enables the observer to select a role model without recognizing the resemblance and, nevertheless, wishing to emulate the model in whole or in part.

Gibson [38] (p. 136) clarifies the meaning of the role model expression on the basis of two theoretical constructs, namely, 'the concept of role and the tendency of individuals to identify with other people ... and the concept of modeling, the psychological matching of cognitive skills and patterns of behavior between a person and an observing individual'. So individuals are attracted to role models that are perceived as similar in terms of their characteristics, behaviour, or goals (role aspect) and from whom they are able to learn certain skills or competencies (model aspect) [9]. In the literature [26,30], the phenomenon of role models is explained by the theory of identification (role) and the theory of social learning.

As noted by Bosma et al. [9], role identification can be seen as a cognitive response to an individual's conviction that another person's characteristics (the model) are close to their own motivations and character [44], and that this model plays a desirable social role or occupies an attractive position [45]. Bosma et al. [9] observed that identification of roles can be manifested by forming or adapting individual preferences [46], through imitative behaviour [44], motivational and inspirational effects [41], or legitimacy and encouragement [47-49].

Social learning theory and social cognitive theory $[50,51]$ argue that individuals are attracted to role models that can help them develop further by learning new tasks and skills [38]. Therefore, individuals learn by following examples of people who perform well in an area in which they themselves want to be involved or excel [9].

Entrepreneurial role models can range from people in the individual's close circle (relatives, friends, colleagues, acquaintances) to well-known national or international personalities, but with whom the individual has not interacted personally, such as Bill Gates or Steve Jobs, for example. A role model 
can be a real one, when an individual has a direct relationship with the role model, or it can be a virtual role model, with no interaction, but who can be followed on TV, performing live, on radio, or reading about it [43].

Role models can influence the entrepreneurial approaches of individuals in different stages of the entrepreneurial process, fulfilling varied roles, such as facilitator in detecting opportunities and generating business ideas in the innovation stage, stimulating in the event-triggering stage and legitimizing during the implementation phase, as getting to know successful entrepreneurs makes the act of becoming one yourself seem more credible [16]. People in close contact with an entrepreneurial role model are more inclined to develop a desire and confidence to create their own businesss [23]. Also, the influence of entrepreneurial models can appear in various forms [23]:

- A greater likelihood for a person to adopt entrepreneurial intentions when he or she is personally acquainted with individuals who have recently become entrepreneurs. The presence of an entrepreneurial role model in the family or in close social environment can make a person contemplate such a career alternative and/or shift cognitive attention towards the search for possible entrepreneurial opportunities [19].

- A focus of the individual's attention on specific opportunities inspired by activities of the role model that modify his/her cognitive perceptions as to favour his/her decision to actively pursue entrepreneurial activities aimed at creating his/her own business [21].

- Influence of assessing an option to set up a business through cognitive representation and comparison with other existing entrepreneurs [20]. The final decision to actually start a new business is most often based on the subjective assessment of the founding decision over other alternative career and life options [38]. According to Fornahl [20], positive entrepreneurial examples can lead to an increased likelihood for setting up a firm.

Bosma et al. [9] identified three main lines of research in the empirical literature exploring the link between the presence of entrepreneurial models and the decision to become an entrepreneur: effect of parental role models, influence of networks and peer groups, and regional perspective (or regions with high levels of entrepreneurship).

The first line of research investigates the effect of parental role models, respectively, the existence of a positive relationship between the decision to start a business and having parents who are, or have been, entrepreneurs, a relationship explained especially through genetic inheritance, the possibility of learning from the business and family, or having financial support. Studies on family background pinpoint the positive relationship between the presence of role models in the family and the emergence of entrepreneurs. Collins, Moore, and Unwalla [52] were the first who empirically verified whether the influence to set up a new venture goes back to entrepreneur's childhood and family circumstances [8]. Fayolle, Gailly, and Lassas-Clerc [2] stated that business creation intentions are stronger when the degree of self-efficacy increases due to presence of entrepreneurial role models, and when influence comes from several close relatives.

Parental role models can influence children in becoming entrepreneurs. According to Brennan, Morris and Schindehutte [53], children of entrepreneurial mothers, who perceive their role models as positive and successful, are prone to imitate these role models [54]. At the same time, many business owners involve children in their businesses from an early age. This situation increases the likelihood that a young potential entrepreneur will develop an affinity for entrepreneurship more or less through osmosis and will absorb useful entrepreneurial knowledge and experience when entering the entrepreneurial world by joining a family business, starting a new business, or buying a business [36].

The second line of research discusses the influence of networks and peer groups on the decision to become an entrepreneur by offering entrepreneurial models and access to information.

Baucus and Human [55] studied retirees from companies included in the Fortune 500 who then started their own businesses, and found three main factors that positively affect the entrepreneurial 
process [36]: networking, vision of departure (voluntary vs. involuntary), and previous employment experience, which included either owning a business or having an entrepreneurial role model.

Another way in which social networks and support groups contribute to stimulating entrepreneurial actions is given by the fact that entrepreneurs use their social networks to search for information about markets, industries, administrative regulations, and potential pitfalls [9].

The third line of research that focuses on the association between exposure to entrepreneurial models and the decision to become an entrepreneur is one that adopts an aggregate, regional perspective, in which regions with high levels of entrepreneurship can encourage the emergence of new entrepreneurial initiatives by facilitating finding a suitable example or obtaining information or resources from other entrepreneurs. At the same time, the presence of other entrepreneurs contributes to the legitimation of aspirations and entrepreneurial actions [49].

Concerning the influence of role models on entrepreneurial career choice, Karimi et al. [56] identified in the literature two hypotheses on the relationship between role models and career choice: the first hypothesis is based on Social Cognitive Career Theory [57] and argues that career models serve as contextual support, having a direct effect on the career decision-making process, which means that the presence of role models or their knowledge directly influences entrepreneurial career intentions and options [22]; the second hypothesis is based on the Theory of Planned Behaviour [15], and suggests that role models, as exogenous factors, indirectly influence career-related intention through its antecedents, and this means that role models affect entrepreneurial intention, but only if they affect the person's attitude $[14,15]$ and perceived ability to succeed in a new business. Kolvereid [17] also concluded that role models indirectly influence intentions by their effect on the antecedents of career choice intentions, namely attitude, subjective norms, and perceived behavioural control [56].

\subsection{Entrepreneurship Education of Students Using Successful Entrepreneurial Role Models}

Watson [58] points out that education of an entrepreneur differs from simple employee training, underlining the major role of education and study on final results.

As for entrepreneurial education of the young, especially in terms of entrepreneurial spirit development among this category, the European Commission developed the Entrepreneurship Action Plan 2020 [10], which is based on the following strategies: development of education and training in the field of entrepreneurship; creation of proper business environment; models and involvement of specific groups. Both educational institutions and successful entrepreneurs, who can be true models in influencing one's entrepreneurial attitude and intention, can play an important role in the entrepreneurial education of the young $[59,60]$.

Entrepreneurship education exposes students to examples of successful business planning, or to proactive interaction with successful practitioners [61,62]. Bae et al. [63] argue that such pedagogical elements provide coping strategies, which contribute to maintaining motivation and interest, leading to higher expectations of success [64] and to increased entrepreneurial self-efficacy [65].

Gibson [38] (p. 149) observes that the importance of role models consists of three interdependent functions: "to provide learning, to provide motivation and inspiration and to help individuals define their self-concept". Nauta and Kokaly [66] also argue that role models can provide to entrepreneurs practical support and guidance, calling this component learning through support.

Bosma et al. [9] summarize the functions of entrepreneurial role models defined by Gibson [38] and by Nauta and Kokaly [66] as four interdependent functions: (i) inspiration and motivation (the role model creates awareness and motivates people to start), (ii) increasing self-efficacy (the role model makes people confident that they can reach a certain goal); (iii) learning by example (the role model provides guidance for action) and (iv) learning through support (the role model provides assistance or practical advice). The authors argue that the first two functions result (indirectly) from the theory of role identification, while the third and fourth are implied by the theory of social learning. 
2.3.1. Entrepreneurship Education through Successful Entrepreneurial Models and Entrepreneurial Intention

Bae et al. [63] discuss the two theoretical perspectives arguing that entrepreneurship education is positively correlated with entrepreneurial intentions: the human capital theory [67] and the entrepreneurial self-efficacy [68].

Recent empirical studies [69-71] confirm the link between human, financial, and social capital, on the one hand, and entrepreneurship, on the other hand. In this context, entrepreneurial role models can be seen as a possible source of relevant human or social capital.

Martin, McNally, and Kay [72] found a statistically significant relationship between entrepreneurship education and human capital outcomes, such as knowledge and skills related to entrepreneurship, a positive perception of entrepreneurship and entrepreneurial intentions.

According to findings of Liñán and Fayolle [73] in their extensive systematic literature review on entrepreneurial intentions, among the background factors that influence the entrepreneurial intentions of individuals, it is the influence of role models that attracts the greatest attention. In this respect, family role models seem to be more prominent [74], but other models also exert a positive effect $[9,75]$. Studies have shown that between $35-70 \%$ of entrepreneurs had entrepreneurial role models [14]. Informal surveys among students from entrepreneurship courses at universities support this claim. The reasoning behind this vision is that business owners share their wisdom and practical knowledge with students [36].

Educational institutions and media every year strive to provide students and the general public with entrepreneurial role models in the classroom, on TV, and in the press [21].

Entrepreneurship education is also associated with entrepreneurial self-efficacy that can enhance entrepreneurial intentions $[65,76]$, as it refers to confidence in one's ability to successfully perform various roles and tasks related to entrepreneurship [63]. Role models, in particular, can stimulate self-efficacy by providing vicarious experiences to students. They can also enhance individual self-efficacy by providing encouragement and feedback, as well as by increasing positive emotional reactions to entrepreneurship [56].

Recent studies approach the decision to enter and remain in entrepreneurship from the perspective of individual motivation. The motivational approach to explaining an entrepreneurial behaviour is based on the idea that a person needs to possess a favourable predisposition towards entrepreneurship in order to create a business [77]. In this body of theory, Barba-Sánchez and Atienza-Sahuquillo [77] view a significant contribution from the Expectancy Theory, since rational prioritization influences the effect of individual intentions on the motivation-decision-action process. Accordingly, the motivation for behaviour selection (the decision to behave or act in a certain way) is determined by the desirability of the outcome (what is to be the expected result of that selected behaviour) [77,78]. Therefore, the Expectancy Theory provides a framework for understanding why and how people choose to be entrepreneurs [79].

In their research, Barba-Sánchez and Atienza-Sahuquillo [77] found evidence that an individual's motivation to become self-employed is based on the subjective probability that his or her efforts will be followed by a specific outcome and the attractiveness of that outcome. They also verified that the attraction of being self-employed for a given person depends on his/her perception that it will lead to desirable outcomes.

In the body of theory that studies the role of motivation in the formation of entrepreneurial intentions, one line of research uses the self-determination theory to explain the motivational processes involved in an entrepreneurial behaviour. Self-determination theory posits that people tend to move toward activities that satisfy their inner resources of development and optimal functioning [80]. So, people can be intrinsically or extrinsically motivated, or both, to engage in entrepreneurial activity [81].

Al-Jubari, Hassan, and Liñán [80] investigated the role of basic psychological needs of autonomy, competence, and relatedness as conceptualized in self-determination theory in shaping university student attitudes and intentions towards entrepreneurship. Their most relevant result was the 
confirmation that both intrinsic and extrinsic motivations can lead to entrepreneurial intention and, through it, to actually starting up new ventures.

The results reported by studies such as those of Barba-Sánchez and Atienza-Sahuquillo [77] and Al-Jubari, Hassan, and Liñán [80] stress the significant role that schools and universities play in motivating students in the development of their entrepreneurial career. In this regard, role models can also have a motivational impact [75] on choosing to become an entrepreneur.

2.3.2. Entrepreneurship Education through Successful Entrepreneurial Models and Attitude towards Entrepreneurship

Previous studies investigating the influence of entrepreneurial models on student perception of entrepreneurship pay special attention to the exposure of students to local entrepreneurs.

Hartshorn and Parvin [82] suggested a training programme that includes mentorship provided by local entrepreneurs. In this programme, a mentor is assigned to each student, enabling the student to take part in all business decisions [83]. This type of training offers to students the opportunity to get a more precise knowledge of what an entrepreneur is, as well as the opportunity to be introduced as a potential future entrepreneur into a local business environment [84].

Another method suggested for enriching entrepreneurship knowledge with the help of local entrepreneurs is by organizing 'socialization' seminars [85], where they will be invited along with important stakeholders to the business community. These meetings give participants the opportunity to learn who is who in the world of local business, to establish important contacts, to solve certain doubts they may have, and to strengthen their motivation [83].

Byabashaija and Katono [86] believe that using case studies of local entrepreneurs in teaching entrepreneurship can be instructive regarding the feasibility of entrepreneurship as a career option.

Van Auken, Fry and Stephens [87] studied the impact of specific activities, in which role models and students, as potential entrepreneurs, might be involved in the students' desires to own their own businesses. They found the activities of role models related to the respondent's involvement in professional activities, employment in the business, and discussions about the business to be significantly related to the interest in starting a business [54].

Karimi et al. [56] propose other ways to include local entrepreneurs in the entrepreneurial education process, namely, teachers can invite entrepreneurs take part in question and answer sessions with students, present their success stories, and share their experiences. Invited entrepreneurs can provide real-life examples of how small businesses are created and run, giving students a clearer sense of the real world of entrepreneurship and a better understanding of the challenges and opportunities they may face as entrepreneurs.

According to Urbano et al. [88], universities are ideal scenarios for joining people with entrepreneurial experience to those who want to create a new venture. Guerrero and Urbano [89] recommend seminars, business meetings, and labs as places for the interaction between potential role models and the university students.

The results of the study conducted by Karimi et al. [56] suggest that entrepreneurship education programmes should consider including contact with entrepreneurial models as part of their curriculum as these models can stimulate student confidence in their ability to start a business and improve their attitude towards entrepreneurship.

On long-term, Urbano et al. [88] propose that scenarios where experienced entrepreneurs interact with potential entrepreneurs should be created to enhance the entrepreneurial attitudes and motivation toward entrepreneurship within the university community.

In light of the above and in line with our three-fold objective, the key research questions of this paper are:

RQ1. Which are the characteristics that graduate students use the most to describe a successful entrepreneur? 
RQ2. Does exposure to successful entrepreneurial role models within entrepreneurship education classes increase the entrepreneurial intentions of graduate students?

RQ3. Does exposure to successful entrepreneurial role models within entrepreneurship education classes really influence the attitudes of graduate students towards entrepreneurship?

\section{Materials and Methods}

\subsection{Participants and Data Collection}

This study is based on an experimental session conducted within a course of Business Creation during one academic semester (15 February 2019-30 May 2019), in which first-year master's students enrolled in the Business Administration master's programme took part. The number of participants was 30 graduates, representing $100 \%$ of the students enrolled in this programme. Experiment participants had different undergraduate backgrounds (law, economics, sports, philosophy, etc.) and fell into different age groups of graduate students interested in acquiring competences in entrepreneurship. The sample comprised $53.33 \%$ of business-related and $46.67 \%$ of non-business related majors (10\% Law, 6.67\% Humanities, 6.67\% Theology, 3.33\% Pedagogy, 3.33\% Psychology, 3.33\% Food Science and Engineering, 3.33\% Medical Bioengineering, 3.33\% Physical Education, 3.33\% Architecture, 3.33\% Public Administration). It consisted of 9 male (30\%) and 21 female students $(70 \%)$. Most respondents were aged between $21-25$ (70\%), with an average age of 26.23. The demographic characteristics of study participants are shown in Appendix A.

The main reasons for including this group of graduates in the sample were their diverse undergraduate backgrounds and the fact that they had chosen a master's programme in business administration, which made them eligible for becoming future entrepreneurs. Moreover, according to Barba-Sanchez and Atienza-Sahuquillo [7], the use of student samples in research of entrepreneurial intentions is adequate as such samples enable researchers to work with individuals currently involved in real career-choice processes and to examine psychological processes prior to new venture creation as an alternative to working for somebody else [90].

To reach the study objectives, the pilot experiment was divided into five phases, disaggregated into the activities listed below:

1. At the beginning of the semester, students were given a questionnaire with closed questions regarding their entrepreneurial intention and attitude towards entrepreneurship. It included 11 statements related to the following themes: Level of entrepreneurial intention (5 variables), Personal attitude towards entrepreneurship —What do you associate entrepreneurship with and to what extent? (6 variables).

2. In order to identify the profile of a successful entrepreneur in the students' view, they were asked to write a brief essay outlining what characteristics they consider to define a successful entrepreneur.

3. Each student then had to choose a successful entrepreneurial model, whose success story was presented in class. Students could either conduct a detailed research about a specific entrepreneur (and present it to their peers), or choose a successful entrepreneur who gave a presentation on his or her success story in front of the class. After making presentations, in order to describe the profile of the successful entrepreneurial model that each student chose, each of them filled in a record of a successful entrepreneur, in which they provided data on the entrepreneur's socio-demographic characteristics and entrepreneurial behaviour (sources of business idea, reasons why he/she went into business, main sources of funding of the initial business).

4. After exposure to successful entrepreneurial models, students answered a second questionnaire to assess their entrepreneurial attitudes and intentions after being exposed to successful entrepreneurial models. The final questionnaire included 11 statements related to the two themes included in the initial questionnaire: Level of entrepreneurial intention (5 variables), Personal attitude towards entrepreneurship-What do you associate with entrepreneurship and to what extent? (6 variables). 
5. To identify the students' perceptions of the influence on their entrepreneurial intentions, they were asked to write a short essay explaining how their entrepreneurial intentions and attitudes had been influenced by exposure to successful entrepreneurial models.

\subsection{Data Analysis}

Following Blenker et al. [91] and Barba-Sanchez and Atienza-Sahuquillo [5], we adopted a research methodology that integrated qualitative techniques with quantitative measures in order to get an in-depth understanding of student perceptions of successful entrepreneur profiles and regarding the dynamics of their attitudes towards entrepreneurship and of their entrepreneurial intentions after being exposed to successful entrepreneurial role models. To better assess this experiment, we have used primary sources, i.e., direct interaction with the first-year master's students in Business Administration, the target population of our study.

\subsubsection{Instruments}

Considering the characteristics of this population (graduate students) and the nature of needed information (personal perceptions of entrepreneurship and evolution of entrepreneurial intentions), we used a questionnaire in line with Barba-Sanchez and Atienza-Sahuquillo [5] or Romero, Petrescu, and Balalia (Iosif) [92]. Therefore, we developed a questionnaire on the basis of the reference literature and applied it to participating students both at the start of the study (February, 2019) to identify the starting situation in terms of their entrepreneurial intentions and attitudes, and at the end of the academic semester (May 2019) to analyse and assess the influence of the experiment on their entrepreneurial intentions and attitudes towards entrepreneurship.

Given that intentions are complex cognitive features, capturing entrepreneurial intentions through a direct question is not the most adequate option from a methodological standpoint. Following Liñán and Chen [90] and Romero, Petrescu, and Balalia (Iosif) [92], graduates included in this study were asked about their level of intention using a series of statements related to entrepreneurial activity. The questions used were of seven-point Likert type $(0=$ not at all to $6=$ total $)$. The statement ' $I$ have serious doubts that I'll start a business one day' was formulated in a reverse way in order to control for the respondent's accuracy when answering the questions. So, in this case, the lower level of agreement with the statement also showed higher entrepreneurial intentions of the graduates.

In order to approach the attitudes of students towards entrepreneurship, in accordance with Romero, Petrescu, and Balalia (Iosif) [92], a set of issues related to being an entrepreneur were presented to the interviewed graduates to check as to what extent they personally associated these issues with entrepreneurship. These characteristics were expressed through six statements: being an entrepreneur implies 'facing new challenges', 'creating jobs for other people', 'being creative and innovative', 'getting a high income', 'taking calculated risks' and 'being independent'. These questions were also presented as Likert-type scales with seven items (higher values standing for stronger association/attraction).

The questions were divided into two groups: student entrepreneurial intention (5 items) and student personal attitude towards entrepreneurship ( 6 items). Both sets of used items were adapted from the scales developed by Romero, Petrescu, and Balalia (Iosif) [92].

The consistency of items included in the two applied questionnaires was verified using the Cronbach's Alpha test (Table 1). The values of Cronbach's Alpha coefficients range between 0.678 and 0.712 for each of the four sets of items, indicating a good reliability for these constructs. Some studies view a Cronbach's Alpha coefficient between 0.6 and 0.7 as showing an acceptable reliability. Still, as our values were either below or very close to the generally accepted minimum of 0.70 [93], we performed a principal components factor analysis to each set of items. Although it is adequate for continuous variables, principal components analysis is also frequently used with ordinal data, such as Likert scales. Kaiser-Meyer-Olkin (KMO) Measures higher than 0.50 indicated that a factor analysis may be useful with our data. The significance levels of Bartlett's test of sphericity were less than 0.05, showing significant relationships among variables in each of the four sets of items (Table 2). 
Table 1. Cronbach's Alpha Coefficients.

\begin{tabular}{lccc}
\hline \multicolumn{1}{c}{ Construct } & No. of Items & $\begin{array}{c}\text { Cronbach's } \\
\text { Alpha }\end{array}$ & $\begin{array}{c}\text { Cronbach's Alpha Based on } \\
\text { Standardized Items }\end{array}$ \\
\hline $\begin{array}{l}\text { Entrepreneurial intention before } \\
\text { exposure to successful } \\
\text { entrepreneurial models }\end{array}$ & 5 & 0.712 & 0.756 \\
\hline $\begin{array}{l}\text { Entrepreneurial intention after } \\
\text { exposure to successful } \\
\text { entrepreneurial models }\end{array}$ & 5 & 0.689 & 0.742 \\
\hline $\begin{array}{l}\text { Attitude towards entrepreneurship } \\
\text { before exposure to successful } \\
\text { entrepreneurial models }\end{array}$ & 6 & 0.678 & 0.672 \\
\hline $\begin{array}{l}\text { Attitude towards entrepreneurship } \\
\text { after exposure to successful } \\
\text { entrepreneurial models }\end{array}$ & 6 & 0.702 & 0.713 \\
\hline
\end{tabular}

Table 2. Kaiser-Meyer-Olkin (KMO) Measures and the Significance levels of Bartlett's Test of Sphericity.

\begin{tabular}{lccc}
\hline \multicolumn{1}{c}{ Construct } & $\begin{array}{c}\text { No. of } \\
\text { Items }\end{array}$ & $\begin{array}{c}\text { Kaiser-Meyer-Olkin Measure of } \\
\text { Sampling Adequacy }\end{array}$ & $\begin{array}{c}\text { Sig. for Bartlett's Test of } \\
\text { Sphericity }\end{array}$ \\
\hline $\begin{array}{l}\text { Entrepreneurial intention before } \\
\text { exposure to successful } \\
\text { entrepreneurial models }\end{array}$ & 5 & 0.829 & 0.000 \\
\hline $\begin{array}{l}\text { Entrepreneurial intention after } \\
\text { exposure to successful } \\
\text { entrepreneurial models }\end{array}$ & 5 & 0.575 & 0.019 \\
\hline $\begin{array}{l}\text { Attitude towards entrepreneurship } \\
\text { before exposure to successful } \\
\text { entrepreneurial models }\end{array}$ & 6 & 0.844 & 0.000 \\
\hline $\begin{array}{l}\text { Attitude towards entrepreneurship } \\
\text { after exposure to successful } \\
\text { entrepreneurial models }\end{array}$ & 6 & 0.674 & 0.000 \\
\hline
\end{tabular}

We used essays as a research instrument in order to learn about student conceptions and to understand their perceptions on the characteristics of successful entrepreneurs. In line with Mukoroli [94], to assure the reliability of essays, the teacher sent an email to all the participants explaining the topic of the essay and outlining the guidelines. The students were instructed to write a short essay of about 10-15 lines explaining what successful entrepreneur they had chosen, what motivated their choice (taking into account what criteria), and why they considered the chosen entrepreneur to be a successful one. Participants were encouraged to ask questions in case of any uncertainty.

At the end of the pilot experiment, students were asked to write a final essay of 20-30 lines explaining in what way they had been influenced by the presentations on successful entrepreneurs.

\subsubsection{Content Analysis}

As this was an experimental one-semester-long session within a course of Business Creation, only the students participating in the course (30) were interviewed to assess the influence of their exposure to successful entrepreneurial models on their entrepreneurial intentions, this being a new method of teaching/learning in our institution. For a qualitative research, the sample of 30 respondents was representative, exceeding the threshold of 12 interviewees required in a qualitative analysis as suggested by Onwuegbuzie and Collins [95] and Guest, Bunce, and Johnson [96].

We used content analysis to examine student essays in order to identify the characteristics of a successful entrepreneur in the student view and to assess their perceptions of how their entrepreneurial intentions and attitudes were influenced by being exposed to successful entrepreneurial models. 
The texts were examined minutely as to identify the words and statements describing entrepreneurial success found in the initial essays. The list of these features is shown in Table 3. In the case of final essays, the authors searched for the statements describing what students felt regarding the influence of their participation in the project on their entrepreneurial intentions and attitudes. Citations from student essays are presented and analysed in Section 4.4.

Table 3. The profile of a successful entrepreneur in the students' view.

\begin{tabular}{|c|c|}
\hline Student/Model & Features of a Successful Entrepreneur Defined by Students \\
\hline S1/M1 & $\begin{array}{l}\text { Seriousness, ambition, hard work and a continuous desire for improvement; focuses } \\
\text { on development and innovation. }\end{array}$ \\
\hline S2/M2 & Promotes such values as belief in truth and sincerity. \\
\hline S3/M3 & Power, courage, and wisdom in making business decisions. \\
\hline S4/M4 & Perseverance, morality and risk taking. \\
\hline S5/M5 & $\begin{array}{l}\text { Puts the interest of customers and employees on the foreground ' ... even if he has } \\
\text { sometimes lost'. }\end{array}$ \\
\hline S6/M6 & $\begin{array}{l}\text { Paying attention to details, determination ('started from the bottom, selling } \\
\text { newspapers and now has the largest Romanian restaurant group in the country'). }\end{array}$ \\
\hline S7/M7 & A leader, paying attention to current global issues. \\
\hline S8/M8 & Perseverance and altruism. \\
\hline S9/M9 & Honesty, fairness and trust in people he collaborates with. \\
\hline S10/M10 & Entrepreneurial spirit, philanthropy, emphasis on family values. \\
\hline S11/M11 & Responsible entrepreneur, meant to help humanity. \\
\hline S12/M12 & Perseverance, hard work, lifelong learning. \\
\hline S13/M13 & Entrepreneurial spirit and ambition. \\
\hline S14/M14 & Humanity, family values. \\
\hline S15/M15 & Makes the most of his talent, succeeds in exploiting every opportunity. \\
\hline S16/M16 & A complex person, a good manager; good balance of professional and personal life. \\
\hline S17/M17 & Desire to share with young people his experiences and to guide them. \\
\hline S18/M18 & Perseverance, determination, passion for own business. \\
\hline S19/M19 & A strong, persevering person who never gives up, always achieves his purpose. \\
\hline S20/M20 & Perseverance and entrepreneurial spirit. \\
\hline S21/M21 & Entrepreneurial spirit. \\
\hline S22/M22 & Revolutionizes the technology, 'wanting to do things differently'. \\
\hline S23/M23 & $\begin{array}{l}\text { Morality, common sense and perseverance. 'It is a living example that anything is } \\
\text { possible when you set out to do something and try to do whatever it is necessary to } \\
\text { achieve your ideals'. }\end{array}$ \\
\hline S24/M24 & Makes you evolve and become better. \\
\hline S25/M25 & Family values and perseverance. \\
\hline S26/M26 & Self-confidence. \\
\hline S27/M27 & Modesty, self-confidence. \\
\hline S28/M28 & Successfully combined personal life with professional life. \\
\hline S29/M29 & Responsibility, sacrifice, sincerity, objectivity in the decision-making process. \\
\hline S30/M30 & Insight, civic spirit. \\
\hline
\end{tabular}

We also used content analysis to examine the content of successful entrepreneur records, in which students provided data on entrepreneur socio-demographic characteristics and entrepreneurial behaviour (sources of business ideas, reasons why he/she went into business, main sources of 
funding of the initial business). Appendices $B$ and $C$ present the characteristics of each successful entrepreneurial role model chosen by participants. To assure the correspondence between each student and his entrepreneurial model, we coded student $i$ with $S i$, and the role model with $M i$.

In order to ensure the objectivity of content analysis, all essays and records were double-checked by two authors.

\subsubsection{Descriptive Statistics}

The entrepreneurial intentions of participants and their attitudes towards entrepreneurship before and after exposure to successful entrepreneurial models were assessed using descriptive statistics. The minimum and maximum values, means, modes, and standard deviations were calculated for the scores given by the respondents to each statement and were examined by each variable.

The differences between the distributions of student responses on their entrepreneurial intentions and attitudes were examined comparing the boxplot diagrams corresponding to the two moments considered in the study: before and after exposure to entrepreneurial models.

To observe the differences in the intention and in the attitude of students before and after exposure to successful entrepreneurial models, a set of new variables was created, whose values represent the differences between the scores given by the respondents after the exposure, and those given before the exposure to statements describing entrepreneurial intention and attitude.

\subsubsection{Statistical Testing for Differences}

Despite the existence of nonparametric tests, such as Wilcoxon Signed Ranks Test, suitable for testing the equality of two means for paired samples, in this case, where the same sample was studied at two different time moments, we decided not considering them. Due to a sample size of just 30 graduate students, the use of statistical tests to test for the existence of significant differences between the values corresponding to intention and attitude, recorded in the two moments considered in the analysis (before and after the exposure to the entrepreneurial models), could have brought serious limitations for interpreting and generalizing the results.

\section{Results}

\subsection{Student Perception of Successful Entrepreneur Profile and Behaviour}

Based on the content analysis of the students' initial essays and the information they provided on entrepreneurs in their records, we identified a set of features of successful entrepreneurs.

These features are shown in Table 3.

Generally, students mentioned the following qualities and common values of successful entrepreneurs: perseverance, altruism, responsibility, morality and common sense, ' . . . is correct, with very well defined principles, has morality, he is sincere and transparent and ... he helps you to believe that all good things happen. He is always open-minded to learn new things' (S4 says about M4).

Some participants appreciated the creativity and innovation of a successful entrepreneur as he ' ... revolutionized technology, wanting to do things differently' (S22 about M22) and others noted the focus of entrepreneurs on current global issues: 'is a leader, attentive to current global issues, aiming to improve people's lives' (S7 about M7), 'is a responsible entrepreneur, meant to help humanity' (S11 about M11). Other students noticed that their entrepreneurial role models showed a great entrepreneurial spirit, for instance, giving up on a successful career in the political field to put their skills into practice (S21 about M21), or a good work-life balance as they 'managed to successfully combine their personal and professional life' (S28 about M28).

Another element, through which we shaped the profile of successful entrepreneurs, was the entrepreneurial behaviour. In this study, it is analysed in terms of the following aspects: the source of the business idea, the reason for entering the business environment, and the source of funding.

(a) The Source of Business Idea 
Sasu [97] groups the sources of business ideas into categories that reflect either the macroeconomic trends (demographic, social, technological, and business), or the microeconomic context. Based on the analysis of entrepreneur files filled-in by students, frequently encountered sources of business ideas for the chosen entrepreneurial role models were:

- Previous job (M1, M6).

- $\quad$ Opportunities (M2, M13, M14, M17, M19, M21, M23, M25).

- Passions and hobbies (M5, M15, M18, M23, M24, M25, M28, M30): 'Passion for agriculture and fish farming' (M5), 'Being passionate about sports' (M24).

- Travels: 'traveling to Australia, identifying a new lifestyle' (M4), 'a spiritual journey to India' (M22), 'a trip to Portugal' (M26).

- Books: 'Isaac Asimov's books' (M7), 'Dale Carnegie's book The Secrets of Success' (M8), 'Books read, which influenced his ideas and perception towards life' (M11).

- The family: the continuation of the family tradition in the entrepreneurial field (M3, M29), 'The family, the skills acquired in childhood' (M9), ' ... the idea came from my family ... from my grandmother's vegetable garden' (M21), 'the idea came from the family (mother), traveling abroad and having a vision' (M16).

- National traditions and culture (M30).

(b) The Reason for Entering the Business

Based on content analysis, we found that the entrepreneurial role models that students chose had the following reasons for entering the business environment:

- Financial independence, family welfare (M5, M13, M14, M17, M21); 'To help their family and parents more' (M1), 'financial stability for the family' (M21), 'Out of the need and desire not to live from one day to the next' (M23), 'escaping poverty and hunger helped him get into business' (M24).

- Out of desire to overcome their social status (M15, M20, M27).

- From the desire to 'change the world': 'entered the business to move science, technologies globally' (M7).

- For social reasons: to create jobs (M5), 'helping others' (M16), to promote a healthy life (M9, M12).

- Based on beliefs: the model promoted by parents ' ... never depend on a single income, have more jobs' (M10).

- Desire to dedicate themselves to their passions: 'to do what he likes' (M4), 'giving up the previous job and focusing on an area, where he can put his talents, passion and satisfaction into practice' (M18), 'He wanted his passion to become a reality, or to work for something he is passionate about' (M11).

\section{(c) The Source of Funding}

The financing sources of the entrepreneurs chosen as models by the students were diverse and depended either on the economic, social, and political contexts of the country from which the entrepreneur came, or on the idea and the reason for entering the business.

Following the content analysis of the entrepreneur files filled-in by students, the following business sources were identified:

- Money from their relatives (M1, M12, M17, M29).

- Own sources: personal savings (M4, M6, M10, M15, M16, M18, M25, M28), 'wedding money' (M21); 'own funds made from the sale of some goods, land' (M22), 'little savings and free Internet resources' (M23), the money obtained from previous activities (M24).

- $\quad$ European funds, funding from other institutions (M2, M8, M9, M13, M14, M19, M20, M30).

- Loans (M5, M16).

- Previous ventures: they started the entrepreneurial activity with a small business that they sold and this was the source of funding of another business (M7, M11, M27). 
4.2. Results on Student Entrepreneurial Intentions and Attitudes towards Entrepreneurship before Exposure to Successful Entrepreneurial Models

The descriptive statistics (Table 4) calculated for the variables describing the entrepreneurial intentions of students before exposure to successful entrepreneurial models showed, for the considered sample, a high intensity in entrepreneurial intention (average scores with values between 4.37 and 4.83 , and modal score 6 for variables I1, I2, I4, I5), and a low level of doubts regarding the achievement of the entrepreneurial enterprise (average score of 1.30 and modal score 0 for variable I3).

Table 4. Student entrepreneurial intentions before exposure to successful entrepreneurial models -descriptive statistics.

\begin{tabular}{lcccccc}
\hline & $\mathbf{N}$ & Mean & Mode & $\begin{array}{c}\text { Std. } \\
\text { Deviation }\end{array}$ & Minimum & Maximum \\
\hline $\begin{array}{l}\text { It is very likely that one day I will start } \\
\text { a business (I1) }\end{array}$ & 30 & 4.83 & 6 & 1.315 & 1 & 6 \\
\hline $\begin{array}{l}\text { I am willing to make every effort to } \\
\text { become an entrepreneur (I2) }\end{array}$ & 30 & 4.80 & 6 & 1.270 & 1 & 6 \\
\hline $\begin{array}{l}\text { I have serious doubts that one day I } \\
\text { will end up creating a business (I3) }\end{array}$ & 30 & 1.30 & 0 & 1.601 & 0 & 5 \\
\hline $\begin{array}{l}\text { I am determined to create a business in } \\
\text { the future (I4) }\end{array}$ & 30 & 4.77 & 6 & 1.331 & 1 & 6 \\
\hline $\begin{array}{l}\text { My professional goal is to become an } \\
\text { entrepreneur (I5) }\end{array}$ & 30 & 4.37 & 6 & 1.426 & 1 & 6 \\
\hline
\end{tabular}

Concerning attitude towards entrepreneurship, descriptive statistics (Table 5) showed a positive perception, students associating entrepreneurship especially with creativity and innovation (average score of 5.17 and modal score of 6, minimum score of 3), taking calculated risks (average score of 4.80 and minimum modal score of 4 , minimum score of 3 ) and being independent/being own boss (average score of 4.77 and modal score of 6). Respondents largely associated entrepreneurship with facing new challenges, creating new jobs for other people and generating high income, all statements having average scores higher than 4 .

Table 5. Student attitudes towards entrepreneurship before exposure to successful entrepreneurial models-descriptive indicators: What do you associate with entrepreneurship?

\begin{tabular}{lcccccc}
\hline & N & Mean & Mode & $\begin{array}{c}\text { Std. } \\
\text { Deviation }\end{array}$ & Minimum & Maximum \\
\hline Facing new challenges & 30 & 4.50 & 5 & 1.196 & 2 & 6 \\
Creating new jobs for other people & 30 & 4.30 & 4 & 1.179 & 2 & 6 \\
Creativity and innovation & 30 & 5.17 & 6 & 0.986 & 3 & 6 \\
High income & 30 & 4.30 & 4 & 1.179 & 1 & 6 \\
Assumption of calculated risks & 30 & 4.80 & 4 & 0.925 & 3 & 6 \\
To be independent/to be your own boss & 30 & 4.77 & 6 & 1.194 & 2 & 6 \\
\hline
\end{tabular}

4.3. Assessment of Entrepreneurship Attitudes and Entrepreneurial Intentions of Students after Exposure to Successful Entrepreneurial Models

The descriptive statistical indicators (Table 6) calculated for the variables describing entrepreneurial intentions of students after exposure to successful entrepreneurial models showed a higher average intensity of the entrepreneurial intention (higher average scores, with values between 4.93 and 5.10 , for variables I1, I2, I4, I5), and an equally low average level of doubts towards developing an entrepreneurial enterprise (average score of 1.30 for variable I3). The most important growth (of 0.30 points) was noted for the variable 'I am willing to make all the necessary efforts to become an entrepreneur'. 
Table 6. Student entrepreneurial intentions after exposure to successful entrepreneurial models—descriptive indicators.

\begin{tabular}{lcccccc}
\hline & N & Mean & Mode & $\begin{array}{c}\text { Std. } \\
\text { Deviation }\end{array}$ & Minimum & Maximum \\
\hline $\begin{array}{l}\text { It is very likely that one day I will start a } \\
\text { business (I1) }\end{array}$ & 30 & 5.00 & 6 & 1.050 & 3 & 6 \\
\hline $\begin{array}{l}\text { I am willing to make every effort to } \\
\text { become an entrepreneur (I2) }\end{array}$ & 30 & 5.10 & 6 & 0.923 & 3 & 6 \\
\hline $\begin{array}{l}\text { I have serious doubts that one day I will } \\
\text { end up creating a business (I3) }\end{array}$ & 30 & 1.30 & 1 & 1.368 & 0 & 6 \\
\hline $\begin{array}{l}\text { I am determined to create a business in } \\
\text { the future (I4) }\end{array}$ & 30 & 4.93 & 6 & 1.143 & 2 & 6 \\
\hline $\begin{array}{l}\text { My professional goal is to become an } \\
\text { entrepreneur (I5) }\end{array}$ & 30 & 4.50 & 5 & 1.333 & 6 \\
\hline
\end{tabular}

Analysis of box-plot diagrams of the values for the variables describing entrepreneurial intention at the two time points (before and after exposure) (Figure 1) showed a similar form of the diagrams for high values and a reduced length of the diagram for lower values (for variables I1, I2, I4, I5). This fact could be interpreted as follows: students with medium and high levels of entrepreneurial intention maintained their intensity of intention, while those who did not consider entrepreneurship as an occupational option were willing, after exposure to entrepreneurial models, to take it into consideration. In the case of variable I3, which expresses the level of doubt regarding the development of an entrepreneurial enterprise, the forms of the two diagrams were similar.

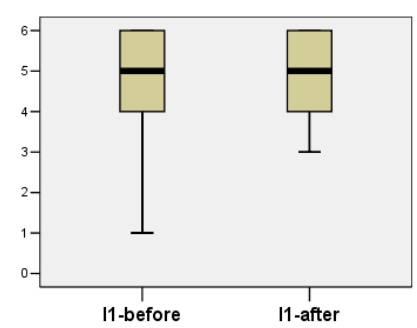

(a)

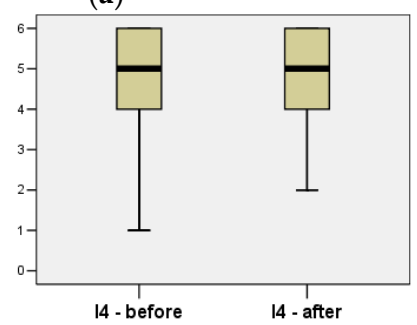

(d)

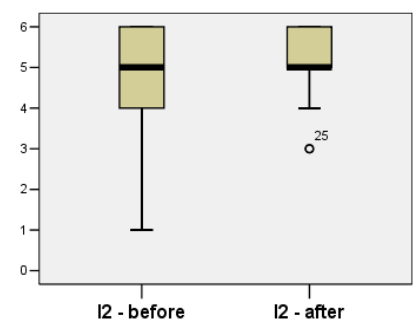

(b)

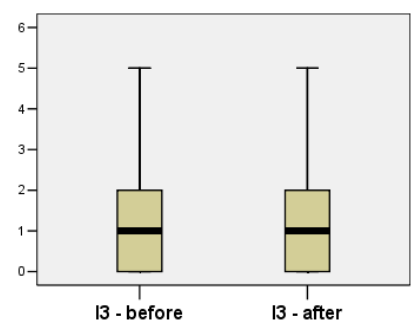

(c)

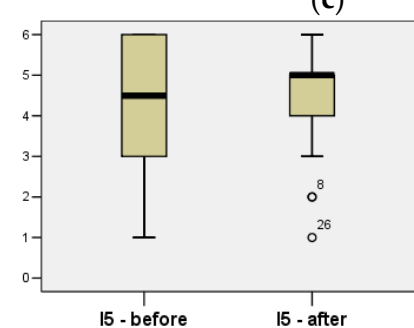

(e)

Figure 1. Distribution of respondents by entrepreneurial intention before and after exposure to successful entrepreneurial models: (a) It is very likely that one day I will create a business for myself; (b) I am willing to make every effort to become an entrepreneur; (c) I have serious doubts that one day I will end up creating a business; (d) I am determined to create a business in the future; (e) My professional goal is to become an entrepreneur.

Table 7 presents distributions of the values of Difference variables for the statements describing entrepreneurial intention. These values were determined as differences between the scores awarded by students after and before their exposure to successful entrepreneurial models. 
Table 7. Differences in student entrepreneurial intentions after exposure to successful entrepreneurial models. ((The bold format in first column is used to emphasize the values of differences in scores.)

\begin{tabular}{|c|c|c|c|c|c|c|c|c|c|c|}
\hline & \multicolumn{2}{|c|}{$\begin{array}{c}\text { Difference: One } \\
\text { day I Will } \\
\text { Probably Start } \\
\text { My Own } \\
\text { Business }\end{array}$} & \multicolumn{2}{|c|}{$\begin{array}{c}\text { Difference: I } \\
\text { Am Willing to } \\
\text { Make Every } \\
\text { Effort to Become } \\
\text { an Entrepreneur }\end{array}$} & \multicolumn{2}{|c|}{$\begin{array}{l}\text { Difference: I } \\
\text { Have Serious } \\
\text { Doubts That } \\
\text { One Day I Will } \\
\text { End up Creating } \\
\text { a Business }\end{array}$} & \multicolumn{2}{|c|}{$\begin{array}{c}\text { Difference: I } \\
\text { Am Determined } \\
\text { to Create a } \\
\text { Business in the } \\
\text { Future }\end{array}$} & \multicolumn{2}{|c|}{$\begin{array}{c}\text { Difference: } \mathrm{My} \\
\text { Professional } \\
\text { Goal is to } \\
\text { Become an } \\
\text { Entrepreneur }\end{array}$} \\
\hline & Count & $\%$ & Count & $\%$ & Count & $\%$ & Count & $\%$ & Count & $\%$ \\
\hline-4 & & & & & 2 & 6.7 & & & & \\
\hline-3 & & & & & 2 & 6.7 & & & & \\
\hline-2 & & & 1 & 3.3 & 1 & 3.3 & 1 & 3.3 & 3 & 10.0 \\
\hline-1 & 5 & 16.7 & 5 & 16.7 & 3 & 10.0 & 6 & 20.0 & 5 & 16.7 \\
\hline 0 & 19 & 63.3 & 14 & 46.7 & 11 & 36.7 & 15 & 50.0 & 12 & 40.0 \\
\hline 1 & 4 & 13.3 & 6 & 20.0 & 7 & 23.3 & 5 & 16.7 & 7 & 23.3 \\
\hline 2 & 1 & 3.3 & 3 & 10.0 & 2 & 6.7 & 2 & 6.7 & 2 & 6.7 \\
\hline 3 & & & & & 1 & 3.3 & & & & \\
\hline 4 & 1 & 3.3 & 1 & 3.3 & & & 1 & 3.3 & 1 & 3.3 \\
\hline 5 & & & & & 1 & 3.3 & & & & \\
\hline Total & 30 & 100 & 30 & 100 & 30 & 100 & 30 & 100 & 30 & 100 \\
\hline
\end{tabular}

1. 'It is very likely that one day I will start my own business': The distribution of respondents by their perceptions of the likelihood of starting a business showed that, after exposure to successful entrepreneurial models, 5 students $(16.7 \%$ ) were less willing to start a business (difference equal to $-1), 19(63.3 \%)$ were equally willing, their intention being unchanged (difference equal to 0 ), while for $6(20.0 \%)$ of the 30 respondents, the intensity of the intention to set up a business increased.

2. 'I am willing to make every effort to become an entrepreneur': After being exposed to successful entrepreneurial models, 6 students $(20.0 \%)$ were less willing to make an effort to become an entrepreneur (the difference equal to -2 or -1 ), 14 students $(46.7 \%)$ were equally willing, their intention being unchanged (difference equal to 0 ), and for 9 of the 30 respondents (33.3\%), the intensity of the intention to make high efforts to become an entrepreneur increased.

3. Regarding the statement 'I have serious doubts that one day I will get to create a company', after exposure to successful entrepreneurial models, 8 students $(26.6 \%)$ experienced a higher level of doubt that they will create an enterprise one day, for 11 students $(36.7 \%)$ the level of doubt remained unchanged, while for the remaining 11 students (36.7\%), it decreased.

4. 'I am determined to create a business in the future': After exposure to successful entrepreneurial models, 7 students $(23.3 \%$ ) were less determined to create a business in the future, 15 students $(50.0 \%)$ were sure, their intention being unchanged (difference equal to 0 ), while, for 8 of the 30 respondents $(26.7 \%)$, the intensity of the decision to set up an enterprise in the future increased.

5. 'My professional goal is to become an entrepreneur': Following the exposure to successful entrepreneurial models, 8 students $(26.7 \%)$ agreed to a lesser degree that their professional goal was to become an entrepreneur, 12 students $(40 \%)$ had the same intensity of intention to consider entrepreneurship as a professional goal, while 10 students (33.3\%) had a higher degree of agreement in relation to establishing entrepreneurship as a professional goal.

The box-plot diagrams showed changes in entrepreneurial intention, especially for the lower scores, namely, an improvement in intention after exposure to successful entrepreneurial models in the cases of students less interested or not interested in entrepreneurship.

Concerning attitude towards entrepreneurship, the descriptive statistics showed that the positive perception was maintained after exposure to successful entrepreneurial models, too. In the final stage of the study (Table 8), Creativity and innovation (average score of 5.13), Being independent/being own boss (average score of 4.90) and Taking calculated risks (average score of 4.50) were still the main elements 
with which students tended to associate entrepreneurship. There was an increase in the average scores for the association of entrepreneurship with Being independent/being own boss and with Creating new jobs for other people, while for the other statements there were slightly lower average scores. The most important change in the perception of entrepreneurship was observed in its association with High income (decrease of the average score from 4.30 to 3.90).

Table 8. Student attitudes towards entrepreneurship after exposure to successful entrepreneurial models-descriptive statistics: What do you associate with entrepreneurship?

\begin{tabular}{lcccccc}
\hline & N & Mean & Mode & $\begin{array}{c}\text { Std. } \\
\text { Deviation }\end{array}$ & Minimum & Maximum \\
\hline Facing new challenges & 30 & 4.37 & 4 & 1.033 & 2 & 6 \\
Creating new jobs for other people & 30 & 4.40 & 5 & 1.070 & 2 & 6 \\
Creativity and innovation & 30 & 5.13 & 6 & 1.008 & 3 & 6 \\
High income & 30 & 3.90 & 3 & 1.242 & 1 & 6 \\
Assumption of calculated risks & 30 & 4.50 & 5 & 0.900 & 3 & 6 \\
To be independent/to be your own boss & 30 & 4.90 & 6 & 1.348 & 1 & 6 \\
\hline
\end{tabular}

The analysis of the box-plot diagrams of the values for the variables describing attitude towards entrepreneurship obtained in the two time points considered in the analysis (Figure 2) showed the following:

- a similar form of the diagrams for the Creativity and innovation variable;

- similar forms of the diagrams, but with slight changes in the concentration of the scores for the variables: Confronting with new challenges (a lower median score), Creating new jobs for other people (a higher median score), Assuming calculated risks (lower number of maximum scores) and Being independent/being your own boss;

- $\quad$ an extension of the chart to lower scores for the High income variable.

The results confirmed the high degree to which students associated entrepreneurship with Creativity and innovation, as well as with an occupation allowing them to maintain their independence. At the same time, after the exposure to successful entrepreneurial models, we noticed a greater orientation of the students' perceptions towards the social benefits of entrepreneurship (Creating new jobs for other people) in comparison to financial ones (High income).

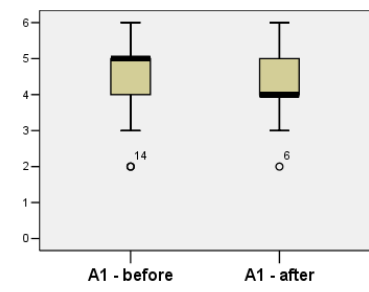

(a)

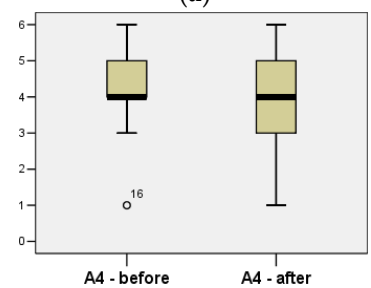

(d)

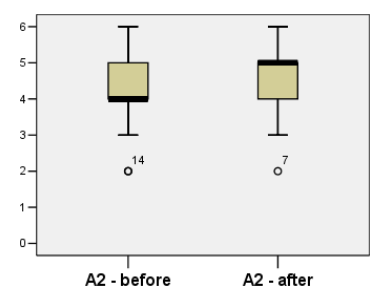

(b)

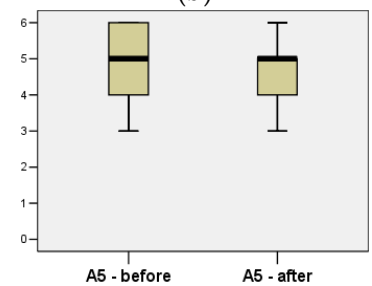

(e)

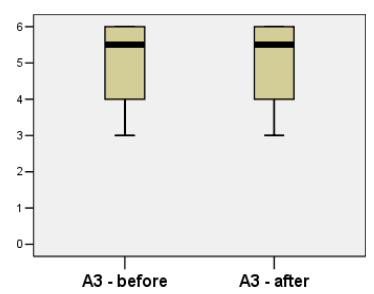

(c)

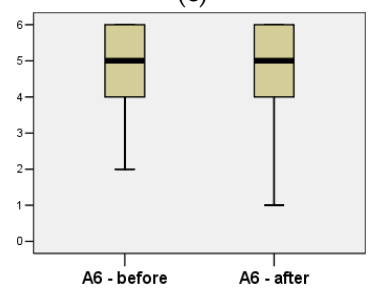

(f)

Figure 2. Distribution of respondents by attitude towards entrepreneurship before and after exposure to successful entrepreneurial models: (a) Confronting with new challenges; (b) Creating new jobs for other people; (c) Creativity and innovation; (d) High income; (e) Assumption of calculated risks; (f) To be independent/to be your own boss. 
Table 9 presents the distributions of values for the Difference variables, matching statements describing attitude towards entrepreneurship. These values were determined as differences between the scores given by students after and before exposure to successful entrepreneurial models.

Table 9. Differences in student attitudes towards entrepreneurship after exposure to successful entrepreneurial models. (The bold format in first column is used to emphasize the values of differences in scores.).

\begin{tabular}{|c|c|c|c|c|c|c|c|c|c|c|c|c|}
\hline & \multicolumn{2}{|c|}{$\begin{array}{l}\text { Difference: } \\
\text { Facing New } \\
\text { Challenges }\end{array}$} & \multicolumn{2}{|c|}{$\begin{array}{l}\text { Difference: } \\
\text { Creating } \\
\text { New Jobs for } \\
\text { Other People }\end{array}$} & \multicolumn{2}{|c|}{$\begin{array}{l}\text { Difference: } \\
\text { Creativity } \\
\text { and } \\
\text { Innovation }\end{array}$} & \multicolumn{2}{|c|}{$\begin{array}{l}\text { Difference: } \\
\text { High Income }\end{array}$} & \multicolumn{2}{|c|}{$\begin{array}{l}\text { Difference: } \\
\text { Assuming } \\
\text { Calculated } \\
\quad \text { Risks }\end{array}$} & \multicolumn{2}{|c|}{$\begin{array}{l}\text { Difference: Being } \\
\text { Independent/Being } \\
\text { Your Own Boss }\end{array}$} \\
\hline & Count & $\%$ & Count & $\%$ & Count & $\%$ & Count & $\%$ & Count & $\%$ & Count & $\%$ \\
\hline-3 & 1 & 3.3 & 1 & 3.3 & 1 & 3.3 & 1 & 3.3 & 1 & 3.3 & 1 & 3.3 \\
\hline-2 & 2 & 6.7 & 1 & 3.3 & 1 & 3.3 & 4 & 13.3 & 4 & 13.3 & 1 & 3.3 \\
\hline-1 & 11 & 36.7 & 7 & 23.3 & 2 & 6.7 & 7 & 23.3 & 9 & 30.0 & 5 & 16.7 \\
\hline 0 & 7 & 23.3 & 10 & 33.3 & 21 & 70.0 & 15 & 50.0 & 9 & 30.0 & 10 & 33.3 \\
\hline 1 & 5 & 16.7 & 8 & 26.7 & 4 & 13.3 & 1 & 3.3 & 4 & 13.3 & 12 & 40.0 \\
\hline 2 & 3 & 10.0 & 2 & 6.7 & 1 & 3.3 & 1 & 3.3 & 2 & 6.7 & 1 & 3.3 \\
\hline 3 & 1 & 3.3 & 1 & 3.3 & & & 1 & 3.3 & 1 & 3.3 & & \\
\hline Total & 30 & 100 & 30 & 100 & 30 & 100 & 30 & 100 & 30 & 100 & 30 & 100 \\
\hline
\end{tabular}

1. Facing new challenges: After exposure to successful entrepreneurial models, 15 students $(46.7 \%)$ associated entrepreneurship with new challenges to a lesser extent, 7 students $(23.3 \%)$ had an unchanged attitude (difference equal to 0 ), while 9 of the 30 respondents $(30.0 \%)$, agreed to a greater extent that entrepreneurship involved facing new challenges.

2. Creating new jobs for other people: Following exposure to successful entrepreneurial models, 9 students $(30.0 \%)$ to a lesser extent associated entrepreneurship with the creation of new jobs for other people, 10 students (33.3\%) had an unchanged attitude, and 11 of the respondents (36.7\%), agreed to a greater extent that entrepreneurship meant creating new jobs for other people.

3. Creativity and innovation: The attitudes of most students, $21(70.0 \%)$, remained unchanged after exposure to successful entrepreneurial models, 4 students (13.3\%) to a lesser extent associated creativity and innovation with entrepreneurship, while 5 respondents $(16.7 \%)$ associated the two phenomena to a greater extent.

4. High income: After exposure to successful entrepreneurial models, 15 students (50.0\%) maintained the same attitude towards associating entrepreneurship with high income, 12 students agreed less $(40.0 \%)$ with this association, only 3 respondents $(10.0 \%)$ claimed more strongly that entrepreneurship involves high income.

5. Assumption of calculated risks: Following the exposure to successful entrepreneurial models, 14 students $(46.7 \%)$ agreed to a lesser extent that entrepreneurship involved assuming calculated risks, 9 students (30.0\%) had the same attitude, while, for 7 of the 30 respondents $(23.3 \%)$, the values of the scores given to the association between entrepreneurship and the calculated risk-taking increased.

6. Being independent/being your own boss: Following exposure to successful entrepreneurial models, most students, $13(43.3 \%)$, associated entrepreneurship to a greater extent with an occupation allowing being independent or being your own boss, 10 students (33.3\%) maintained the same attitude, while 7 respondents $(23.3 \%)$ agreed to a lesser extent that entrepreneurship implied being independent.

\subsection{Student Perceptions of the Influence on Their Entrepreneurial Intentions Due to Exposure to Successful Entrepreneurial Models}

Content analysis of the mini-essays written by students on their perceptions of the ways in which their entrepreneurial intentions and attitudes towards entrepreneurship have been influenced by their exposure to successful entrepreneurial models showed that: 
A high entrepreneurial intention existed before the applied experimental session. After the exposure to successful entrepreneurial models, students felt they gained more confidence in implementing their business ideas and strengthened their desires to become an entrepreneur:

- 'I have to dare and believe that my business idea will work and it will be successful' (S4).

- 'Due to the success stories presented, the students gained more confidence in starting a business' (S5).

- 'The presentations made me become more optimistic and confident' (S11).

- 'Exposure to successful models has aroused my interest in getting into business at one point, they have given me the urge to follow my desire to do what I want' (S15).

- 'The models gave me the courage to do what I want and not to be influenced by others who only speak and do nothing. ... I want to set up my own company!' (S16).

For non-business students, the positive influence of exposure to successful entrepreneurial models was more visible because, besides feeling more confident about their entrepreneurial skills and feeling a greater self-efficacy, they mentioned that the experience of being exposed to successful entrepreneurial role models brought them a better understanding of entrepreneurship and awakened or increased their interest in becoming an entrepreneur.

- 'It made me learn more from the experience of other entrepreneurs to better understand the challenges of this job' (S1-Law).

- 'It has helped me to really discover entrepreneurship and that, having your own business is not difficult, but keeping your business and making it prosper is difficult. It is important how you make the decisions, I learned how to behave in a team and with clients' (S3-Food Engineering).

- 'You must never give up your ideas, but improve them and adapt them according to specific opportunities or situations' (S8-Philology).

- 'Even though I had some ideas about entrepreneurship, I didn't think I was suitable for being an entrepreneur, but due to exposure to successful models I learned that if you have a well-defined idea and you work hard enough you can set up a successful business' (S9-Philology).

- 'Each of us had something to learn from the successful models of entrepreneurs and I understood how much work and perseverance a successful business requires. It has created in my mind a certain entrepreneurial discipline that I did not have before and also built my own confidence' (S12-Pedagogy).

- 'There were very interesting success stories, and our entrepreneurial intentions were influenced by the entrepreneur's personality, his qualities and the way he acted. There have been cases of entrepreneurs who ... from being nobody became somebody. How can you not be influenced and motivated by such a situation?!' (S14-Psychology).

- 'Attending this course has grown my interest to set up a family business. This type of business creates a sense of security, especially when there are harmonious relationships within the family' (S19-Theology).

- 'Exposure to a successful entrepreneurial model had the role of developing my entrepreneurial spirit. Each success story grew in us an entrepreneurial spirit' (S23-Architecture).

- 'Success stories have grown my interest in becoming an entrepreneur' (S24-Physical education).

\section{Discussion and Conclusions}

Nowadays the economic and social changes in society show the importance of developing entrepreneurship and creativity skills [98-100]. The universities, as mentors, and the successful entrepreneurs, as role models for students, can play an important role in the entrepreneurial education of the young and in enhancing their entrepreneurial spirit. From this perspective our study investigated the role of successful entrepreneurial role models in influencing the entrepreneurial intentions of students and their attitudes towards entrepreneurship.

The analysis of descriptions provided by students showed that they describe successful entrepreneurs using characteristics similar to those reported in the literature, such as creativity $[30,34]$ 
and risk-taking [30,31,34]. Most students identified the following characteristics for defining successful entrepreneurs: perseverance ( 8 of 30 respondents), orientation to people and desire to help others ( 7 of 30 respondents), and entrepreneurial spirit ( 5 of 30 respondents). The perseverance feature is in line with the characteristic of increased capacity for intense and lasting effort found by Nastase [31]. Orientation to people and desire to help others confirm the characteristic of orientation towards human capital identified by Amornpinyo [32]. The entrepreneurial spirit feature was also found by Snepar [34], who describes the entrepreneur as a person following an unconventional or unpopular approach to solving a problem.

By studying the entrepreneurial behaviour of successful role models, students learned about sources of business ideas, contexts and reasons for starting a business, and the main funding sources. The characteristics of entrepreneurial behaviour of successful entrepreneurs may represent a source of inspiration and motivation for students to become entrepreneurs themselves.

The analysis of how exposure to successful entrepreneurial models influences student perceptions of entrepreneurship provided evidence on the following issues.

Descriptive statistics of student entrepreneurial intentions before and after exposure to successful entrepreneurial models indicate changes in intention, in both a positive and a negative sense.

The graphical analysis reflects changes in entrepreneurial intention, especially in the area of lower scores, indicating an improvement in intention after exposure to successful entrepreneurial models for students less interested or not interested in entrepreneurship.

In regards to the attitude towards entrepreneurship, descriptive statistical values show a positive perception both before and after exposure to successful entrepreneurial models. In the final stage of the study, we observed that such characteristics of attitude towards entrepreneurship as creativity and innovation, being independent/being your own boss and taking calculated risks were still the main elements the students tended to associate with entrepreneurship. In contrast, there was an increase in average scores for the association of entrepreneurship with being independent/being their own boss and creating new jobs for other people, while for the other statements there were slightly lower average scores. The most important change in the perception of entrepreneurship was observed in its association with high income. So, after exposure to successful entrepreneurial models, we were able to observe a greater orientation of student perceptions towards the social benefits of entrepreneurship (creating new jobs) rather than to financial ones (high income), proving that students have become more aware of this dimension of entrepreneurship.

Our results show that exposing students to success stories of entrepreneurs, viewed by students as role models, is a key influence factor in making the decision to start a business, contributing to the improvement of entrepreneurial intention of less interested or not interested students in entrepreneurship.

In line with previous studies, such as Martin, McNally, and Kay [72], Wilson, Kickul, and Marlino [76] or Zhao, Seibert, and Hills [65], our findings of content analysis and graphical distributions of student perceptions show that learning entrepreneurship by exposure to successful entrepreneurial role models is important in influencing student entrepreneurial intentions and in improving their attitudes towards entrepreneurship. However, the impact of this teaching method is different for graduate business and non-business students (such as literature, architecture, agronomic sciences, psychology, pedagogy, theology, sports, and law).

For the first category of students, entrepreneurial intention might have been high right from the start of the course, as they had already studied many concepts related to business environment that made them more open to entrepreneurship. For these students, the most important consequence of learning from successful entrepreneurship stories may reside in the fact that they felt they had gained more confidence in implementing their business ideas and strengthened their desire to become entrepreneurs. This consequence was observed for many of the students who comprised the sample, irrespective of their degree.

Our results are in line with the study of Karimi, Biemans, Lans, Chizari, Mulder, and Mahdei [56] which suggest that including contact with entrepreneurial models as part of the entrepreneurship education curriculum can stimulate students' confidence in their ability to start a business and improve 
their attitude towards entrepreneurship. The findings of our study also support the approach of Byabashaija and Katono [86], who suggest that using case studies of local entrepreneurs in teaching entrepreneurship can be instructive regarding the feasibility of entrepreneurship as a career option.

The results of our study provide evidence for the theoretical perspective of entrepreneurial self-efficacy [68], which argues that entrepreneurship education is associated with entrepreneurial self-efficacy that can enhance entrepreneurial intentions [65,76]. Role models, in particular, can stimulate individual self-efficacy by providing vicarious experiences to students and by increasing positive emotional reactions to entrepreneurship [56].

As regards non-business students, the positive influence of exposure to successful entrepreneurial models is more visible because, besides feeling more confident in their entrepreneurial capacities and feeling a greater self-efficacy, they mentioned that the experience of being exposed to successful entrepreneurial role models brought them a better understanding of entrepreneurship and awakened or stirred their interest in becoming an entrepreneur.

These findings are in line with those of Bygrave [16], who found that knowing successful entrepreneurs makes the act of becoming one oneself seem more credible, and with the findings of Lafuente, Rialp, and Vaillant [23], who underline that contact with an entrepreneurial role model makes people more inclined towards developing a desire and confidence to create their own businesses. Our findings bring support to the human capital theory [67], a theoretical perspective arguing that entrepreneurship education is positively correlated with entrepreneurial intentions.

Our study provides evidence that entrepreneurship education using successful entrepreneurial role models may influence in a positive sense student entrepreneurial intentions and their attitudes towards entrepreneurship and is in agreement with Hatten and Ruhland [101], who found that students were more likely to become entrepreneurs after attending an entrepreneurship-related programme.

However, our findings show that in order to make this educational method more efficient, entrepreneurship education programmes for master's degrees should be designed differently for business and non-business students. This need emerges from the fact that studying successful entrepreneurial stories impacts the two categories of students differently. This conclusion complies with Teixeira's [102] recommendation that if a goal in designing entrepreneurial programmes is to assist students within and outside the business school, it is important to understand the similarities and differences between business school students and their non-business counterparts.

Our findings also support what Urbano et al. [88] suggest: that courses and curricula of entrepreneurship should be designed so as to take into account the students' profiles.

Although the idea of exploring role models as antecedents of student entrepreneurial intentions is not new, our research adds to the existing literature by considering individuals' (students') own perceptions of entrepreneurial success and their preferences for the chosen role models (the ones they identify with or whom they admire).

This could be a valuable approach for entrepreneurship education as it incorporates higher involvement and participation of students, while exposing them to different perspectives of entrepreneurial success. This way students acquire more knowledge on entrepreneurship by becoming more accustomed with various contexts in which individuals become entrepreneurs, learning about the main sources for business ideas, discovering various business ideas and specific methods for their implementation, and finding out about various methods for dealing with different obstacles that could appear in their entrepreneurial experience.

\section{Limitations and Future Research}

Considering our results and the characteristics of the student sample, we should point out the limitations of the study: first, the sample size comprised only 30 students; second, sample composition favoured the students having a business degree; and third, the statistical analysis treated all sample students equally, although they had different undergraduate degrees. 
Integrating exposure to successful entrepreneurial models into entrepreneurship education programmes for students can be a teaching-learning method with potential from the perspective of sustainable development education as it develops students' entrepreneurial capacities, increases their entrepreneurial intentions and willingness to set up a business.

In order to improve entrepreneurship education as a driver to foster sustainable entrepreneurship among students, more research should be done to identify the appropriate teaching methods for different groups of students. Future studies should use an extended sample and compare various methods for teaching entrepreneurship to students from different study areas. The outcomes of entrepreneurship education might be different when different teaching methods that employ entrepreneurial role models are used (for instance, learning from failure, not only from successful entrepreneurial stories; learning by doing; or learning through support), so this should be further investigated in a future study.

Author Contributions: Conceptualization, G.B., A.M.I.; data curation, G.B., D.B. and A.M.I.; formal analysis, G.B., A.M.I.; investigation, G.B., A.M.I., A.-M.B., D.B., and M.V.B.-G.; methodology, G.B., A.M.I.; resources, G.B., D.B.; software, A.M.I., D.B.; supervision, G.B., A.M.I.; validation, G.B., A.M.I.; visualization, G.B., A.M.I., A.-M.B., D.B. and M.V.B.-G.; writing—original draft, G.B., A.M.I., D.B. and M.V.B.-G.; Writing-review \& editing, G.B., A.M.I., A.-M.B., D.B. and M.V.B.-G. All authors read and approved the final manuscript.

Funding: This research received no external funding.

Acknowledgments: This work was co-financed from the European Social Fund through Operational Programme Human Capital 2014-2020, project number POCU/380/6/13/125015 'Development of entrepreneurial skills for doctoral students and postdoctoral researchers in the field of economic sciences'. This paper also benefited from the support of the Erasmus+ Programme of the European Union, Project Jean Monnet Sustainable Education through European Studies for Young Researchers-SESYR, EACEA, Decision no. 2017-1893/0001-001, Project Number 587359-EPP-1-2017-1-RO-EPPJMO-MODULE.

Conflicts of Interest: The authors declare no conflict of interest.

\section{Appendix A}

Table A1. Student identification data.

\begin{tabular}{|c|c|c|c|}
\hline Student & Gender & Age & Specialization of Graduate Studies \\
\hline S1 & Female & 24 & Law \\
\hline $\mathrm{S} 2$ & Female & 22 & Economic \\
\hline S3 & Female & 23 & Food science and engineering \\
\hline S4 & Female & 25 & Economic \\
\hline S5 & Male & 22 & Finance and Banking \\
\hline S6 & Female & 22 & Management \\
\hline S7 & Male & 25 & Economic \\
\hline S8 & Female & 23 & Humanist, Letters \\
\hline S9 & Female & 22 & Humanist, Letters \\
\hline $\mathrm{S} 10$ & Male & 22 & Economic \\
\hline S11 & Male & 26 & Economic \\
\hline S12 & Female & 23 & Pedagogical \\
\hline $\mathrm{S} 13$ & Female & 28 & Economic \\
\hline S14 & Female & 25 & Psychology \\
\hline S15 & Female & 25 & Law \\
\hline S16 & Female & 39 & Medical bioengineering \\
\hline S17 & Female & 24 & Economy \\
\hline S18 & Female & 22 & Economy \\
\hline S19 & Male & 25 & Theology \\
\hline $\mathrm{S} 20$ & Female & 26 & Economy \\
\hline $\mathrm{S} 21$ & Female & 30 & Economy \\
\hline $\mathrm{S} 22$ & Female & 23 & Economy \\
\hline $\mathrm{S} 23$ & Male & 29 & Architecture \\
\hline S24 & Male & 36 & Physical Education \\
\hline S25 & Female & 40 & Economic statistic \\
\hline S26 & Female & 23 & Economy \\
\hline S27 & Female & 22 & Public Administration \\
\hline $\mathrm{S} 28$ & Female & 23 & Law \\
\hline S29 & Male & 22 & Finance and Banking \\
\hline $\mathrm{S} 30$ & Male & 46 & Theology \\
\hline
\end{tabular}




\section{Appendix B}

Table A2. Identification data for successful entrepreneurial model: socio-demographic characteristics.

\begin{tabular}{|c|c|c|c|c|c|c|c|}
\hline $\begin{array}{c}\text { Entrepreneurial } \\
\text { Model }\end{array}$ & Gender & No. of Children & Current Age & $\begin{array}{l}\text { The Age at Which } \\
\text { He/She Became } \\
\text { an Entrepreneur }\end{array}$ & Field of Studies & Business Field & Level of Studies \\
\hline M1 & Male & 1 & 50 & 25 & Math & DIY & Higher education \\
\hline M2 & Male & 2 & 35 & 23 & Economic & Trade & Higher education \\
\hline M3 & Female & 0 & 35 & 26 & Economic & Trade & Higher education \\
\hline M4 & Male & 3 & 33 & 26 & Economic & Food & Higher education \\
\hline M5 & Male & 3 & 60 & 36 & Economic & Agriculture & Higher education \\
\hline M6 & Male & 0 & 48 & - & Engineering & Restaurant & Higher education \\
\hline M7 & Male & 6 & 47 & 24 & Engineering & Informatics & Higher education \\
\hline M8 & Male & 1 & 40 & 20 & Economic & Informatics & Higher education \\
\hline M9 & Female & 2 & 32 & 26 & Economic & Food & Higher education \\
\hline M10 & Male & 3 & 89 & - & Economic & Financial & Higher education \\
\hline M11 & Male & 6 & 47 & 24 & Engineering & Informatics & Higher education \\
\hline M12 & Female & 1 & 41 & 20 & Medicine & Sports & Higher education \\
\hline M13 & Male & 3 & 45 & 24 & Economic & Appliances & Higher education \\
\hline M14 & Male & 4 & 97 & 20 & Economic & Sales & Higher education \\
\hline M15 & Male & 2 & 65 & 27 & Without studies & Cinematography & $\begin{array}{l}\text { Secondary } \\
\text { education }\end{array}$ \\
\hline M16 & Female & 3 & 39 & 31 & Medical & Medical & Higher education \\
\hline M17 & Male & 3 & 35 & - & Economic & Agriculture & Higher education \\
\hline M18 & Female & 1 & 45 & 40 & Economic & $\begin{array}{c}\text { Floral } \\
\text { arrangements }\end{array}$ & Higher education \\
\hline M19 & Female & 2 & 35 & 24 & Economic & European projects & Higher education \\
\hline
\end{tabular}


Table A2. Cont.

\begin{tabular}{|c|c|c|c|c|c|c|c|}
\hline $\begin{array}{l}\text { Entrepreneurial } \\
\text { Model }\end{array}$ & Gender & No. of Children & Current Age & $\begin{array}{l}\text { The Age at Which } \\
\text { He/She Became } \\
\text { an Entrepreneur }\end{array}$ & Field of Studies & Business Field & Level of Studies \\
\hline M20 & Male & 2 & 65 & 31 & Sports & Coffee shops & Higher education \\
\hline M21 & Male & 1 & 28 & 24 & Political Sciences & Food & Higher education \\
\hline M22 & Male & 4 & 56 & 28 & IT & IT & Higher education \\
\hline M23 & Female & 0 & 35 & - & Arts & $\begin{array}{l}\text { Electronic } \\
\text { commerce }\end{array}$ & Higher education \\
\hline M24 & Male & 3 & 80 & 40 & Sports & Sports, leasing & Higher education \\
\hline M25 & Female & 1 & 54 & 25 & Medicine & Fashion & Higher education \\
\hline M26 & Female & 0 & 35 & 29 & Economic & Trade in teas & Higher education \\
\hline M27 & Male & 2 & 83 & 27 & Without studies & Textiles & $\begin{array}{l}\text { Secondary } \\
\text { education }\end{array}$ \\
\hline M28 & Male & 2 & 32 & 18 & Engineering & $\begin{array}{c}\text { Electrical } \\
\text { installations }\end{array}$ & Higher education \\
\hline M29 & Female & 1 & 30 & 19 & Medicine & Translations & Higher education \\
\hline M30 & Male & 1 & 60 & 21 & Agrarian & Agriculture & Higher education \\
\hline
\end{tabular}




\section{Appendix C}

Table A3. Aspects of entrepreneurial behaviour for the success model.

\begin{tabular}{|c|c|c|c|}
\hline The Model Chosen by the Student & Source for Business Idea & Reason for Entering the Business & Funding Source \\
\hline M1 & -previous job & -to help their family and parents more & -money from in-laws \\
\hline M2 & $\begin{array}{l}\text {-identification of a new niche; } \\
\text { lack of a network of shops }\end{array}$ & -to develop their leadership capabilities; & -business idea funded by a big company \\
\hline M3 & $\begin{array}{l}\text {-family; comes from a family of } \\
\text { entrepreneurs }\end{array}$ & -continuing family tradition & -own income and parental help \\
\hline M4 & $\begin{array}{l}\text {-travel to Australia and discovering a } \\
\text { new lifestyle, nutrition }\end{array}$ & -personal satisfaction & -personal savings \\
\hline M5 & -passion for agriculture and fish farming & $\begin{array}{l}\text {-financial independence but also for } \\
\text { social reasons-providing jobs for } \\
\text { citizens }\end{array}$ & $\begin{array}{l}\text {-personal and family savings; later, for } \\
\text { business development he frequently } \\
\text { resorted to bank loans and leasing }\end{array}$ \\
\hline M6 & -previous job & $\begin{array}{l}\text {-being attracted by a business model } \\
\text { discovered in a previous job }\end{array}$ & -personal savings \\
\hline M7 & -books of Isaac Asimov & $\begin{array}{l}\text {-entered the business to 'move science } \\
\text { technologies globally' }\end{array}$ & $\begin{array}{l}\text {-previous business, funded together with } \\
\text { some colleagues }\end{array}$ \\
\hline M8 & $\begin{array}{l}\text {-Dale Carnegie's book The Secrets of } \\
\text { Success }\end{array}$ & $\begin{array}{l}\text {-the post-communist period (the system } \\
\text { of social ordering); } \\
\text {-books of psychology and personal } \\
\text { development }\end{array}$ & -bank loans \\
\hline M9 & $\begin{array}{l}\text {-family, skills acquired in childhood but } \\
\text { also awards won in food competitions } \\
\text { gave him courage and confidence }\end{array}$ & -promoting healthy eating & $\begin{array}{l}\text {-the financing programme SRL-D but } \\
\text { also bank loans }\end{array}$ \\
\hline
\end{tabular}


Table A3. Cont.

\begin{tabular}{|c|c|c|c|}
\hline The Model Chosen by the Student & Source for Business Idea & Reason for Entering the Business & Funding Source \\
\hline M10 & $\begin{array}{l}\text {-a professor of finance and stock } \\
\text { exchanges at the university }\end{array}$ & $\begin{array}{l}\text {-the model promoted by parents ' ... } \\
\text { never depend on a single income, have } \\
\text { more jobs' }\end{array}$ & -own sources \\
\hline M11 & $\begin{array}{l}\text {-read books influenced his ideas and } \\
\text { perception on life }\end{array}$ & $\begin{array}{l}\text {-he wanted his passion to become a } \\
\text { reality, or to work for something he is } \\
\text { passionate about }\end{array}$ & $\begin{array}{l}\text {-money used from the sale of the first } \\
\text { business (financed with little money) } \\
\text { was the source for another business }\end{array}$ \\
\hline M12 & $\begin{array}{l}\text {-desire to help as many people as } \\
\text { possible, social context }\end{array}$ & $\begin{array}{l}\text {-promoting sport combined with healthy } \\
\text { eating }\end{array}$ & -loan from relatives \\
\hline M13 & -opportunity & -financial independence & -bank loans \\
\hline M14 & -opportunity & -responsibility to the family & -bank loans \\
\hline M15 & -talent, passion & $\begin{array}{l}\text { - desire to overcome their social } \\
\text { condition }\end{array}$ & -personal savings \\
\hline M16 & -family (mother), travels abroad & -helping others & -own sources, but also bank loans \\
\hline M17 & -opportunity & -determination, financial independence & -relatives \\
\hline M18 & -passion & $\begin{array}{l}\text {-giving up his/her previous job and } \\
\text { focusing on an area where he can put } \\
\text { his/her talents, passion into practice and } \\
\text { bring satisfaction }\end{array}$ & -own income \\
\hline M19 & $\begin{array}{l}\text {-opportunities provided by European } \\
\text { integration }\end{array}$ & -it was his duty to help others & -own funds, but also bank loans \\
\hline M20 & -participation in a fair/exhibition & -desire to overcome his condition & -non-refundable European funds \\
\hline M21 & $\begin{array}{l}\text {-from family ... 'from the grandmother's } \\
\text { vegetable garden'; opportunity-new } \\
\text { concept on the market }\end{array}$ & -financial stability for the family & -the wedding money \\
\hline
\end{tabular}


Table A3. Cont.

\begin{tabular}{|c|c|c|c|}
\hline The Model Chosen by the Student & Source for Business Idea & Reason for Entering the Business & Funding Source \\
\hline M22 & $\begin{array}{l}\text {-the idea came after a spiritual journey to } \\
\text { India }\end{array}$ & $\begin{array}{l}\text {-entered the business being influenced by } \\
\text { a friend, after which he discovered his } \\
\text { entrepreneurial spirit }\end{array}$ & $\begin{array}{l}\text {-own funds resulting from the sale of } \\
\text { goods }\end{array}$ \\
\hline M23 & -passion; opportunity & $\begin{array}{l}\text {-financial reasons; 'from the need and } \\
\text { desire not to live from one day to } \\
\text { another' }\end{array}$ & $\begin{array}{l}\text {-few economies and free Internet } \\
\text { resources }\end{array}$ \\
\hline M24 & $\begin{array}{l}\text {-passion for sport; he obtained money } \\
\text { from sport, then he did business in the } \\
\text { sports field }\end{array}$ & -financial reasons, poverty alleviation & $\begin{array}{l}\text {-funds obtained through sports activities; } \\
\text {-knowledge and connections created } \\
\text { through sport }\end{array}$ \\
\hline M25 & -passion and opportunity & $\begin{array}{l}\text {-desire to do what he likes; although he } \\
\text { completed his studies in another field, he } \\
\text { chose to put his talents into practice, his } \\
\text { passion }\end{array}$ & -family income \\
\hline M26 & -trip to Portugal; opportunity & -financial independence & -European funds non-refundable \\
\hline M27 & -previous job & $\begin{array}{l}\text {-financial reasons; he wanted to } \\
\text { overcome his condition }\end{array}$ & $\begin{array}{l}\text {-from personal savings he opened a } \\
\text { smaller business then he sold it and with } \\
\text { the money obtained he set up another } \\
\text { business }\end{array}$ \\
\hline M28 & -passion & -professional and financial independence & -own income \\
\hline M29 & -business inherited from parents & $\begin{array}{l}\text {-continuation of business inherited from } \\
\text { the father }\end{array}$ & -income of the inherited enterprise \\
\hline M30 & $\begin{array}{l}\text {-Romanian traditions and culture; } \\
\text { passion }\end{array}$ & -financial independence & -bank loans \\
\hline
\end{tabular}




\section{References}

1. Barringer, B.; Jones, F.; Neubaum, D. A quantitative content analysis of the characteristics of rapid-Growth firms and their founders. J. Bus. Ventur. 2005, 20, 663-687. [CrossRef]

2. Fayolle, A.; Gailly, B.; Lassas-Clerc, N. Assessing the impact of entrepreneurship education programmes: A new methodology. J. Eur. Ind. Train. 2006, 30, 701-720. [CrossRef]

3. Packham, G.; Jones, P.; Miller, C.; Pickernell, D.; Thomas, B. Attitudes towards entrepreneurship education: A comparative analysis. Educ. Train. 2010, 52, 568-586. [CrossRef]

4. Mueller, S. Increasing entrepreneurial intention: Effective entrepreneurship course characteristics. Int. J. Entrep. Small Bus. 2011, 13, 55-74. [CrossRef]

5. Barba-Sánchez, V.; Atienza-Sahuquillo, C. The development of entrepreneurship at school: The Spanish experience. Educ. Train. 2016, 58, 783-796. [CrossRef]

6. Yemini, M.; Haddad, J. Engineer-Entrepreneur: Combining technical knowledge with entrepreneurship education. The Israel case study. Int. J. Eng. Educ. 2010, 26, 1220-1229.

7. Barba-Sáncheza, V.; Atienza-Sahuquillo, C. Entrepreneurial intention among engineering students: The role of entrepreneurship education. Eur. Res. Manag. Bus. Econ. 2018, 24, 53-61. [CrossRef]

8. Veciana, J.; Aponte, M.; Urbano, D. University Students' Attitudes towards Entrepreneurship: A Two Countries Comparison. Int. Entrep. Manag. J. 2005, 1, 165-182. [CrossRef]

9. Bosma, N.; Hessels, J.; Schutjens, V.; van Praag, M.; Verheul, I. Entrepreneurship and Role Models. J. Econ. Psychol. 2012, 33, 410-424. [CrossRef]

10. European Commission. The Entrepreneurship 2020 Action. Available online: https://ec.europa.eu/growth/ smes/promoting-entrepreneurship/action-plan_en (accessed on 29 May 2019).

11. Lina, D.M.; Ionescu, A.M.; Bedrule-Grigoruță, M.V. Entrepreneurial orientation in Romanian Higher Education. In Proceedings of the 11th International Conference on Education and New Learning Technologies, Palma, Spain, 1-3 July 2019; pp. 9864-9872. [CrossRef]

12. Pittaway, L.; Cope, J. Entrepreneurship education a systematic review of the evidence. Int. Small Bus. J. 2007, 25, 479-510. [CrossRef]

13. Nabi, G.; Liñán, F.; Fayolle, A.; Krueger, N.; Walmsley, A. The Impact of Entrepreneurship Education in Higher Education: A Systematic Review and Research Agenda. Acad. Manag. Learn. Educ. 2017, 16, 277-299. [CrossRef]

14. Scherer, R.F.; Adams, J.S.; Carley, S.S.; Wiebe, F.A. Role model performance effects on development of entrepreneurial career preference. Entrep. Theory Pract. 1989, 13, 53-72. [CrossRef]

15. Krueger, N. The impact of prior entrepreneurial exposure on perceptions of new venture feasibility and desirability. Entrep. Theory Pract. 1993, 18, 5-21. [CrossRef]

16. Bygrave, W.D. Theory building in the entrepreneurship paradigm. In Entrepreneurship Perspectives on Theory Building; Bull, I., Thomas, H., Willard, G., Eds.; Elsevier: Oxford, UK, 1995; pp. 129-158.

17. Kolvereid, L. Prediction of employment status choice intentions. Entrep. Theory Pract. 1996, $21,47-57$. [CrossRef]

18. Krueger, N.; Reilly, M.; Carsrud, A. Competing models of entrepreneurial intentions. J. Bus. Ventur. 2000, 15, 411-432. [CrossRef]

19. Shane, S. Prior knowledge and the discovery of entrepreneurial opportunities. Organ. Sci. 2000, 11, 448-469. [CrossRef]

20. Fornahl, D. Entrepreneurial activities in a regional context. In Cooperation, Networks, and Institutions in Regional Innovations Systems; Fornahl, D., Brenner, T., Eds.; Edward Elgar: Cheltenham, UK, 2003; pp. 38-57.

21. Venkataraman, S. Regional transformation through technological entrepreneurship. J. Bus. Ventur. 2004, 19, 153-167. [CrossRef]

22. Van Auken, H.; Stephens, P.; Fry, F.; Silva, J. Role model influences on entrepreneurial intentions: A comparison between USA and Mexico. Int. Entrep. Manag. J. 2006, 2, 325-336. [CrossRef]

23. Lafuente, E.M.; Rialp, J.; Vaillant, Y. Regional differences in the influence of Role-Models: Comparing the Entrepreneurial Process of Rural Catalonia. Reg. Stud. 2007, 41, 779-795. [CrossRef]

24. Asimakopoulos, G.; Hernández, V.; Peña Miguel, J. Entrepreneurial Intention of Engineering Students: The Role of Social Norms and Entrepreneurial Self-Efficacy. Sustainability 2019, 11, 4314. [CrossRef]

25. Marian, L. The Entrepreneur and The Entrepreneurship; EFI ROM Press: Targu Mureş, Romania, 2007. 
26. Viramgami, H.S. Fundamentals of entrepreneurship; A.P.H. Publishing Corporation: New Delhi, India, 2007.

27. Drucker, P.F. Innovation and Entrepreneurship, 1st ed.; Routledge: London, UK, 2014. [CrossRef]

28. Shapero, A.; Sokol, L. The Social Dimensions of Entrepreneurship. Encycl. Entrep. 1982, 72-90. Available online: https://papers.ssrn.com/sol3/papers.cfm?abstract_id=1497759 (accessed on 6 February 2020).

29. Schumpeter, J.A. The Crisis in Economics-Fifty Years Ago. J. Econ. Lit. 1982, 20, 1049-1059.

30. Gartner, W. Who Is an Entrepreneur? Is the Wrong Question. Entrep. Theory Pract. 1989, 13. [CrossRef]

31. Nastase, C. Antreprenoriat și tehnici decizionale în afaceri internationale. 2012. Available online: http: //www.seap.usv.ro (accessed on 28 May 2019).

32. Amornpinyo, N. The Characteristics of Entrepreneurs with Successful and Sustainable Small Businesses in Northeastern Thailand. Pertanika J. Soc. Sci. Hum. 2018, 26, 113-128.

33. Przepiorka, A. What makes successful entrepreneurs different in temporal and goal-Commitment dimensions? Time Soc. 2016, 25. [CrossRef]

34. Snepar, J.; Fishman, E.K.; Horton, K.M.; Johnson, P.T. Launching a Successful Startup: An Entrepreneur's Field Guide. J. Am. Coll. Radiol. 2018, 15, 1521-1522. [CrossRef]

35. Duchek, S. Entrepreneurial resilience: A biographical analysis of successful entrepreneurs. Int. Entrep. Manag. J. 2018, 14, 429-455. [CrossRef]

36. Fry, F.L.; Van Auken, H. The Influence of Role Models in Entrepreneurial Intentions. J. Dev. Enterp. 2003, 11, 157-167. [CrossRef]

37. Shapiro, E.; Haseltine, F.; Rowe, M. Moving up: Role-Models, mentors, and the "patron-system". Sloan Manag. Rev. 1978, 19, 51-58.

38. Gibson, D.E. Role models in career development: New directions for theory and research. J. Vocat. Behav. 2004, 65, 134-156. [CrossRef]

39. Schein, E. Career Dynamics: Matching Individual and Organizational Needs; Addison-Wesley: Reading, MA, USA, 1978.

40. Ajzen, I. The theory of planned behavior. Organ. Behav. Hum. Decis. Process. 1991, 50, 179-211. [CrossRef]

41. Krumboltz, J.; Mitchell, A.; Jones, G. A social learning theory of career selection. Couns. Psychol. 1976, 6, 71-80. [CrossRef]

42. Gibson, D.E. Developing the professional self-Concept: Role model construals in early, middle, and late career stages. Organ. Sci. 2003, 14, 591-610. [CrossRef]

43. McCullough, C.M. Do Role Models Matter? Exploring the Correlates of Motivational and Imitative Role Modeling by Professionals. Doctoral Dissertation, Philosophy of Business Administration Faculty of the Graduate School, University of Missouri, Columbia, MO, USA, 2013.

44. Kagan, J. The concept of identification. Psychol. Rev. 1958, 65, 296-305. [CrossRef] [PubMed]

45. Bell, A. Role modelship and interaction in adolescence and young adulthood. Dev. Psychol. 1970, 2, $123-128$. [CrossRef]

46. Witt, U. Economics, sociobiology, and behavioral psychology on preferences. J. Econ. Psychol. 1991, 12, 557-573. [CrossRef]

47. Arenius, P.; De Clercq, D. A network-Based approach on opportunity recognition. Small Bus. Econ. 2005, 24, 249-265. [CrossRef]

48. Koellinger, P.; Minniti, M.; Schade, C. I think I can, I think I can: Overconfidence and entrepreneurial behavior. J. Econ. Psychol. 2007, 28, 502-527. [CrossRef]

49. Mueller, P. Entrepreneurship in the region: Breeding ground for nascent entrepreneurs? Small Bus. Econ. 2006, 27, 41-58. [CrossRef]

50. Bandura, A. Social Learning Theory; General Learning Press: New York, NY, USA, 1971.

51. Bandura, A. Social Foundations of Thought and Action Englewood Cliffs, NJ: Prentice-Hall. In The Health Psychology Reader; Marks, D., Ed.; Sage Publications: London, UK, 1986; pp. 94-106.

52. Collins, O.F.; Moore, D.G.; Unwalla, D.B. The Enterprising Man; MSU Business Studies, Michigan State University: East Lansing, MI, USA, 1964.

53. Brennan, C.; Morris, M.; Schindehutte, M. Entrepreneurs and motherhood: Impacts on their children in South Africa and United States. J. Small Bus. Manag. 2003, 41, 1. [CrossRef]

54. Muofhe, N.J.; Du Toit, W.F. Entrepreneurial education's and entrepreneurial role models' influence on career choice. SA J. Hum. Resour. Manag. 2011, 9. [CrossRef] 
55. Baucus, D.A.; Human, S.E. Second-Career entrepreneurs: A multiple case study analysis of entrepreneurial processes and antecedent variables. Entrep. Theory Pract. 1995, 19, 41-71. [CrossRef]

56. Karimi, S.; Biemans, H.J.A.; Lans, T.; Chizari, M.; Mulder, M.; Mahdei, K.N. Understanding role models and gender influences on entrepreneurial intentions among college students. Procedia Soc. Behav. Sci. 2013, 93, 204-214. [CrossRef]

57. Lent, R.W.; Brown, S.D.; Hackett, G. Toward a unifying social cognitive theory of career and academic interest, choice, and performance. J. Vocat. Behav. 1994, 45, 79-122. [CrossRef]

58. Watson, K.; Hogarth Scott, S.; Nicholas Wilson, N. Small Business start-Ups: Success factors and support implication. Int. J. Entrep. Behav. Res. 1998, 14, 217-233. [CrossRef]

59. Boldureanu, G.; Lache, C.; Păduraru, T.; Boldureanu, D.; Niculescu, N. Students' entrepreneurial competencies and orientation. Current status and perspectives. Environ. Eng. Manag. J. 2013, 12, 2071-2077. [CrossRef]

60. Stoian (Bobâlcă), C.; T,ugulea, O.; Maha, L.G.; Ciobanu, C.I. What is Different about Volunteers? A Study on Factors of Buying Decisions of Products with Recycled Content. Sustainability 2018, 10, 1631. [CrossRef]

61. Honig, B. Entrepreneurship education: Toward a model of contingency-based business planning. Acad. Manag. Learn. Educ. 2004, 3, 258-273. [CrossRef]

62. Titrek, O.; Ilgin, I.; Ozturk, O.; Ozturk, A. Teachers' Opinions on the Functionality of Educational Projects. In Proceedings of the 4th International Conference on Lifelong Learning and Leadership for all (ICLEL 2018), Wroclaw, Poland, 3-5 July 2018; pp. 392-403.

63. Bae, T.J.; Qian, S.; Miao, C.; Fiet, J.O. The relationship between entrepreneurship education and entrepreneurial intentions: A meta-Analytic review. Entrep. Theory Pract. 2014, 38, 217-254. [CrossRef]

64. Stumpf, S.A.; Brief, A.P.; Hartman, K. Self-Efficacy expectations and coping with career-Related events. J. Vocat. Behav. 1987, 31, 91-108. [CrossRef]

65. Zhao, H.; Seibert, S.E.; Hills, G.E. The mediating role of self-Efficacy in the development of entrepreneurial intentions. J. Appl. Psychol. 2005, 90, 1265-1272. [CrossRef]

66. Nauta, M.M.; Kokaly, M.L. Assessing role model influence on students' academic and vocational decisions. J. Career Assess. 2001, 9, 81-99. [CrossRef]

67. Becker, G.S. Human Capital, 2nd ed.; University of Chicago Press: Chicago, IL, USA, 1975.

68. Chen, C.C.; Greene, P.G.; Crick, A. Does entrepreneurial self-Efficacy distinguish entrepreneurs from managers? J. Bus. Ventur. 1998, 13, 295-316. [CrossRef]

69. Davidsson, P.; Honig, B. The role of social and human capital among nascent entrepreneurs. J. Bus. Ventur. 2003, 18, 301-331. [CrossRef]

70. Parker, S.; Van Praag, M. Schooling, capital constraints and entrepreneurial performance: The endogenous triangle. J. Bus. Econ. Stat. 2006, 24, 416-431. [CrossRef]

71. Van Praag, M.; van Witteloostuijn, A.; van der Sluis, J. Returns for Entrepreneurs Versus Employees: The effect of Education and Personal Control on the Relative Performance of Entrepreneurs; Discussion Paper TI 2009-111/3; Tinbergen Institute: Amsterdam, Holland, 2009.

72. Martin, B.C.; McNally, J.J.; Kay, M.J. Examining the formation of human capital in entrepreneurship: A meta-analysis of entrepreneurship education outcomes. J. Bus. Ventur. 2013, 28, 211-224. [CrossRef]

73. Liñán, F.; Fayolle, A. A systematic literature review on entrepreneurial intentions: Citation, thematic analyses, and research agenda. Int. Entrep. Manag. J. 2015, 11, 907-933. [CrossRef]

74. Carr, J.C.; Sequeira, J.M. Prior family business exposure as intergenerational influence and entrepreneurial intent: A theory of planned behavior approach. J. Bus. Res. 2007, 60, 1090-1098. [CrossRef]

75. Radu, M.; Loué, C. Motivational impact of role models as moderated by "ideal" vs. "ought selfguides" identifications. J. Enterprising Cult. 2008, 16, 441-465. [CrossRef]

76. Wilson, F.; Kickul, J.; Marlino, D. Gender, entrepreneurial self-Efficacy, and entrepreneurial career intentions: Implications for entrepreneurship education. Entrep. Theory Pract. 2007, 31, 387-406. [CrossRef]

77. Barba-Sánchez, V.; Atienza-Sahuquillo, C. Entrepreneurial motivation and self-Employment: Evidence from expectancy theory. Int. Entrep. Manag. J. 2017, 13, 1097-1115. [CrossRef]

78. Lawler, E.E.; Suttle, J.L. Expectancy theory and job behavior. Organ. Behav. Hum. Perform. 1973, 9, $482-503$. [CrossRef] 
79. Locke, E.A.; Baum, J.R. Entrepreneurial motivation. In The Psychology of Entrepreneurship; SIOP organizational Frontiers series; Baum, J.R., Frese, M.R.A., Baron, R.A., Eds.; Erlbaum: Mahwah, NJ, USA, 2007; pp. $93-112$.

80. Al-Jubari, I.; Hassan, A.; Liñán, F. Entrepreneurial intention among University students in Malaysia: Integrating self-Determination theory and the theory of planned behavior. Int. Entrep. Manag. J. 2019, 15, 1323-1342. [CrossRef]

81. Naffziger, D.W.; Hornsby, J.S.; Kuratko, D.F. A proposed research model of entrepreneurial motivation. Entrep. Theory Pract. 1994, 18, 29-42. [CrossRef]

82. Hartshorn, C.; Parvin, W. Teaching entrepreneurship: Creating and implementing a naturalistic model. In Proceedings of the International Conference EURO PME, Rennes, France, 30 September-2 October 1999.

83. Liñán, F.; Rodríguez-Cohard, J.C.; Rueda-Cantuche, J.M. Factors affecting entrepreneurial intention levels: A role for education. Int. Entrep. Manag. J. 2011, 7, 195-218. [CrossRef]

84. Gibb, A.A. Entrepreneurial core capacities, competitiveness and management development in the 21st century. In Proceedings of the IntEnt98-Conference, European Business School, Schloß Reichartshausen, Frankfurt, Germany, 27-29 July 1998.

85. Kent, C.A. Entrepreneurship education at the collegiate level: A synopsis and evaluation. In Entrepreneurship Education: Current Developments, Future Directions; Kent, C.A., Ed.; Quorum Books; Greenwood Publishing Group: Westport, CT, USA, 1990.

86. Byabashaija, W.; Katono, I. The impact of college entrepreneurial education on entrepreneurial attitudes and intention to start a business in Uganda. J. Dev. Entrep. 2011, 16, 127-144. [CrossRef]

87. Van Auken, H.; Fry, F.L.; Stephens, P. The Influence of Role Models on Entrepreneurial Intentions. J. Dev. Entrepren. 2006, 11, 157-167. [CrossRef]

88. Urbano, D.; Aparicio, S.; Guerrero, M.; Noguera, M.; Torrent-Sellens, J. Institutional determinants of student employer entrepreneurs at Catalan universities. Technol. Forecast. Soc. 2017, 123, 271-282. [CrossRef]

89. Guerrero, M.; Urbano, D. The development of an entrepreneurial university. J. Technol. Transf. 2012, 37, 43-74. [CrossRef]

90. Liñán, F.; Chen, Y.W. Development and cross-Cultural application of a specific instrument to measure entrepreneurial intentions. Entrep. Theory Pract. 2009, 33, 593-617. [CrossRef]

91. Blenker, P.; Elmholdt, S.T.; Frederiksen, S.H.; Korsgaard, S.; Wagner, K. Methods in entrepreneurship education research: A review and integrative framework. Educ. Train. 2014, 56, 697-715. [CrossRef]

92. Romero, I.; Petrescu, R.M.; Balalia (Iosif), A.E. Universities as Suppliers of Entrepreneurship Education Services. The Cases of The University of Seville and The Academy of Economic Studies in Bucharest. Amfiteatru Econ. 2011, 13, 347-361.

93. Hair, J.F., Jr.; Black, W.C.; Babin, B.J.; Anderson, R.E. Multivariate Data Analysis, 7th ed.; Pearson Education Limited: Harlow, UK, 2014.

94. Mukoroli, J.N. An investigation of academic writing at the University of Namibia: Engendering an Experiential, Meaningful and Critical Pedagogy for English for Academic Purposes. Ph.D. Thesis, Faculty of Education, University of the Western Cape, Cape Town, South Africa, November 2016.

95. Onwuegbuzie, A.J.; Collins, K.M. A typology of mixed methods sampling designs in social science research. Qual. Rep. 2007, 12, 281-316.

96. Guest, G.; Bunce, A.; Johnson, L. How many interviews are enough? An experiment with data saturation and variability. Field Methods 2006, 18, 59-82. [CrossRef]

97. Sasu, C. Initierea si dezvoltarea afacerilor; Polirom: Bucarest, Romania, 2003.

98. Titrek, O. (Ed.) Entrepreneurship via Creativity for European Citizenship in Education; Lambert Academic Publishing: Saarbrucken, Germany, 2015.

99. Titrek, O.; Celik, O. Relations between Self-Awareness and Transformational Leadership Skills of School Managers. New Educ. Rev. 2011, 23, 355-369.

100. Titrek, O. The Level of Innovation Management of School Principals' in Turkey. Antropologist 2015, 19, 449-456. [CrossRef] 
101. Hatten, T.S.; Ruhland, S.K. Student attitude toward entrepreneurship as affected by participation in an SBI program. J. Educ. Bus. 1995, 70, 224-227. [CrossRef]

102. Teixeira, A.A.C. Entrepreneurial Potential in Engineering And Business Courses ... Why Worry Now? In Innovation in Manufacturing Networks. In Proceedings of the BASYS 2008, IFIP-The International Federation for Information Processing, Porto, Portugal, 23-25 June 2008; Azevedo, A., Ed.; IFIP-The International Federation for Information Processing. Springer: Boston, MA, USA, 2008. [CrossRef]

(C) 2020 by the authors. Licensee MDPI, Basel, Switzerland. This article is an open access article distributed under the terms and conditions of the Creative Commons Attribution (CC BY) license (http://creativecommons.org/licenses/by/4.0/). 